\title{
Perceptions of West Virginia Beef Cattle Producers on Preparedness for an Agroterrorism Attack
}

\author{
Rebecca Laura Ours \\ West Virginia University
}

Follow this and additional works at: https://researchrepository.wvu.edu/etd

\section{Recommended Citation}

Ours, Rebecca Laura, "Perceptions of West Virginia Beef Cattle Producers on Preparedness for an Agroterrorism Attack" (2010). Graduate Theses, Dissertations, and Problem Reports. 3058.

https://researchrepository.wvu.edu/etd/3058

This Thesis is protected by copyright and/or related rights. It has been brought to you by the The Research Repository @ WVU with permission from the rights-holder(s). You are free to use this Thesis in any way that is permitted by the copyright and related rights legislation that applies to your use. For other uses you must obtain permission from the rights-holder(s) directly, unless additional rights are indicated by a Creative Commons license in the record and/ or on the work itself. This Thesis has been accepted for inclusion in WVU Graduate Theses, Dissertations, and Problem Reports collection by an authorized administrator of The Research Repository @ WVU. For more information, please contact researchrepository@mail.wvu.edu. 


\section{Perceptions of West Virginia Beef Cattle Producers on Preparedness for an Agroterrorism Attack}

\section{Rebecca Laura Ours}

Thesis submitted to the

Davis College of Agriculture, Natural Resources and Design

at West Virginia University

in partial fulfillment of the requirements

for the degree of

\section{Master of Science}

in

Agricultural and Extension Education

Deborah A. Boone, Ph.D., Chair

Harry N. Boone, Jr. Ph.D.

Jean M. Woloshuk, Ed.D.

Division of Resource Management

Morgantown, West Virginia

2010

Keywords: Biosecurity, beef producers, agroterrorism 


\section{ABSTRACT \\ Perceptions of West Virginia Beef Cattle Producers on Preparedness for an Agroterrorism Attack}

\section{Rebecca Laura Ours}

Biosecurity is a measure that can help protect beef producers from financial loss associated with an agroterrorism attack. This study sought to determine West Virginia beef producers' perceptions of the potential for agroterrorism and what biosecurity measures they practice. A mailed questionnaire was sent to a sample population of 355 beef producers, with a response rate of $47.7 \%$. Beef producers in West Virginia agreed that agroterrorism could happen in the United States and in West Virginia; however, the majority did not feel it would happen on their farms. A majority of the respondents indicated they would attend a program on agroterrorism and that their most common source of information on biosecurity measures was popular agriculture magazines. Isolating new animals was perceived to be the most important biosecurity measure that could be practiced on their farms, but less than half of the producers reported that they isolated new cattle. 


\section{DEDICATION}

I dedicate this study to myself for all the hard work and perseverance over the past five and a half years that have helped me to accomplish so much. 


\section{ACKNOWLEDGEMENTS}

First and most importantly, I would like to give a special thanks to my advisor Dr. Debby Boone. She has given me the inspiration and the motivation to accomplish my goals. I appreciate everything she has done for me.

My committee members Dr. Harry Boone and Dr. Jean Woloshuk are two great people and I enjoyed working with them throughout the years. I appreciate everything they have done to make my goals and dreams come true. Anytime I needed help they were always there to answer my questions.

I would like to thank my grandparents for being there for me during my years of college. I appreciate all the things they have done for me. They were there through the rough times of my aggravation of writing my thesis. I love you very much!

Maw maw, Grant, and Linda, even though you are not here to share my accomplishments, I am always thinking of you all. I know you all are my angels and are guiding me each day. I love you all!

Allison and Ethan, you two mean the world to me. I hope that I have been a good role model for you both. I hope that you always stick to your dreams and goals like I have done over the past years. I want you to know that I will always love you and hope you will have many accomplishments to be proud of like your older sister. I love you and thanks for always being there for me! 


\section{TABLE OF CONTENTS}

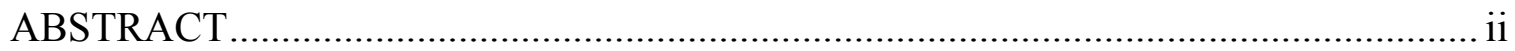

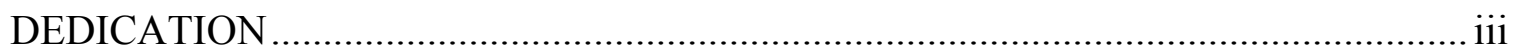

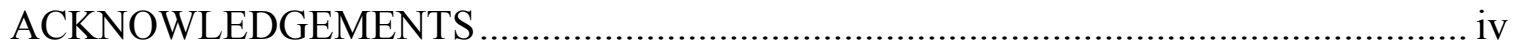

TABLE OF CONTENTS .................................................................................

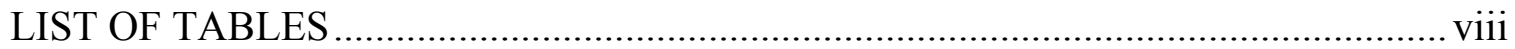

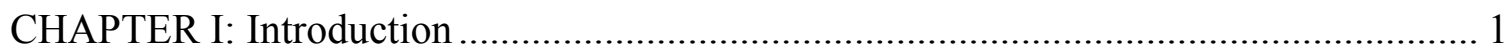

Problem Statement ................................................................................ 4

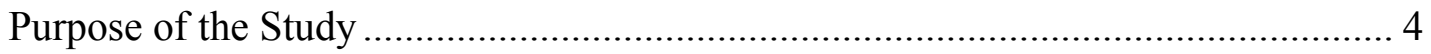



CHAPTER II: Review of Literature ........................................................................... 5





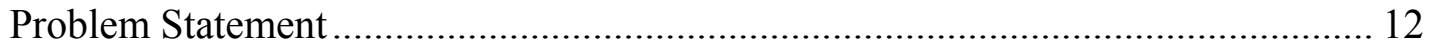



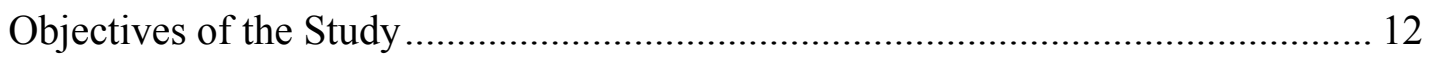

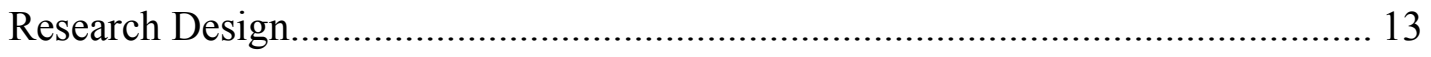

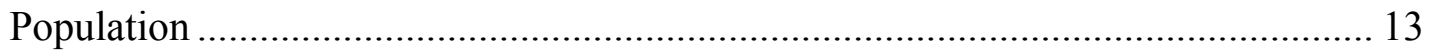

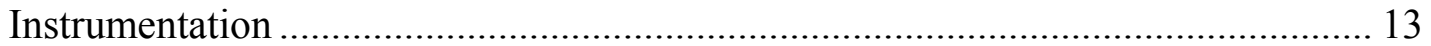

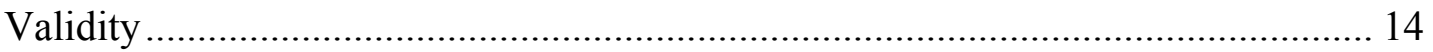




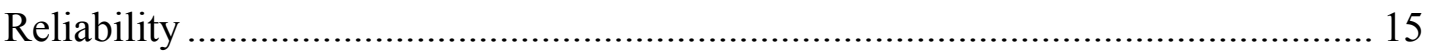



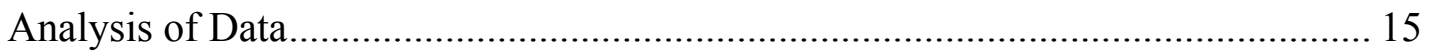

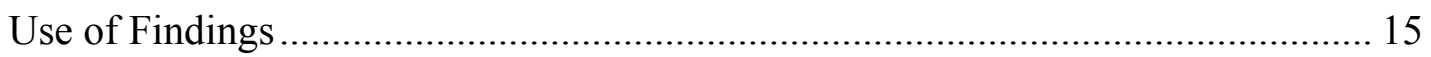

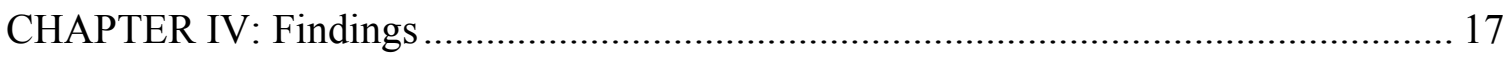

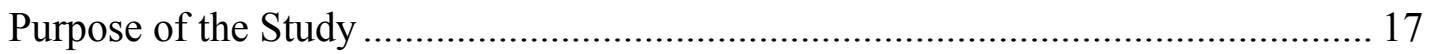

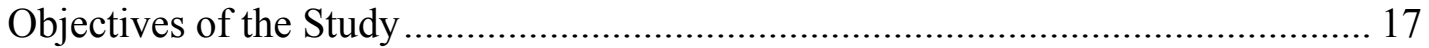

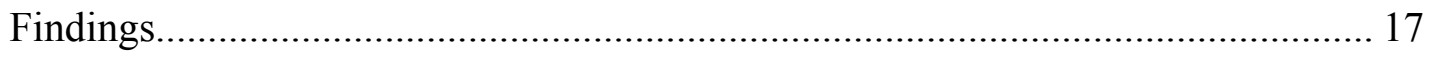

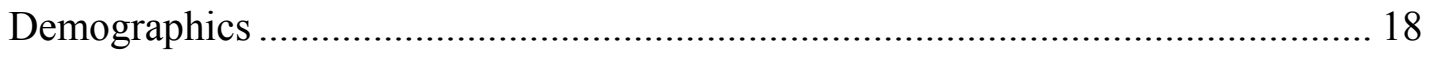

Cattle on Operation ....................................................................................... 19



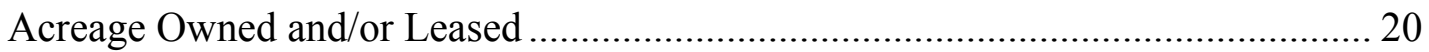

Perceptions and Preparedness for an Agroterrorism Attack ..................................... 22

Perceived Threats to Farm ............................................................................ 24

Attended Workshop on Biosecurity-Agroterrorism............................................... 28

Where Producers would Seek Advice in Event of an Act of Agroterrorism ............ 28

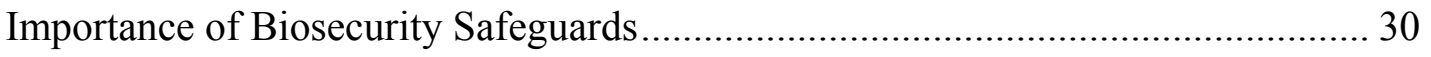

Likelihood Producer would Contact an Individual/Agency for Additional

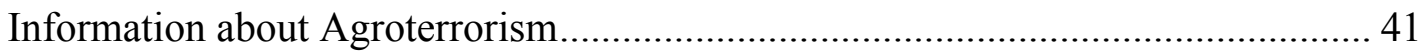

Access to Education Material to Answer Beef Cattle Biosecurity Questions .......... 49 
Use of Published Sources for Additional Information about Agroterrorism

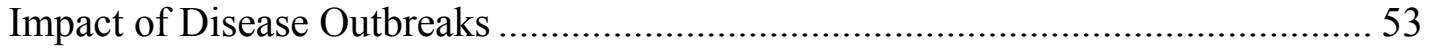

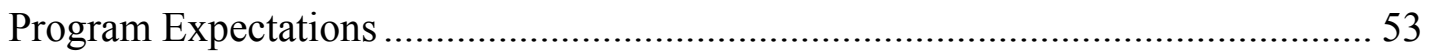

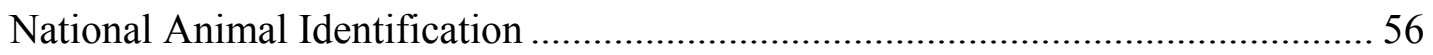

CHAPTER V: Summary, Discussion, Conclusions, and Recommendations................... 58

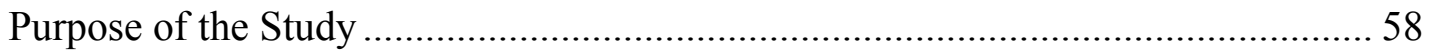

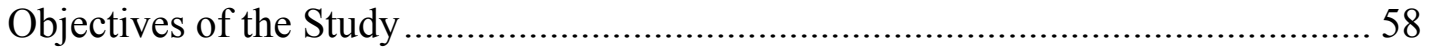

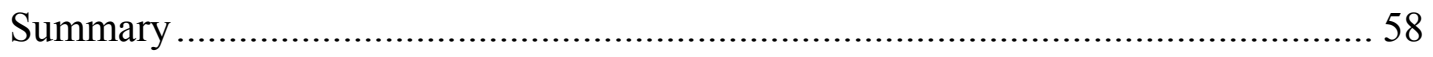

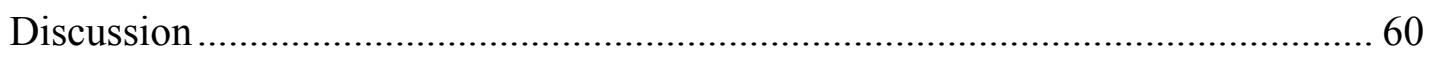

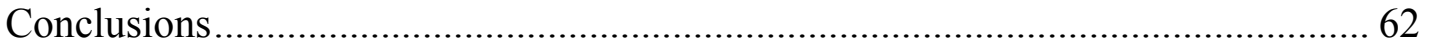

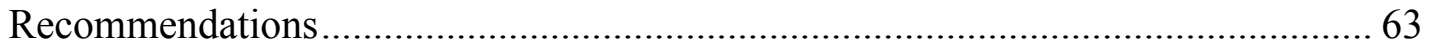

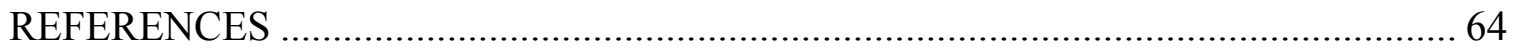

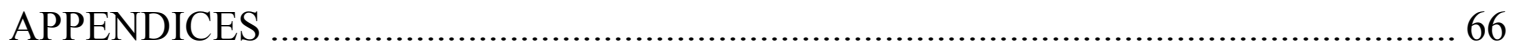

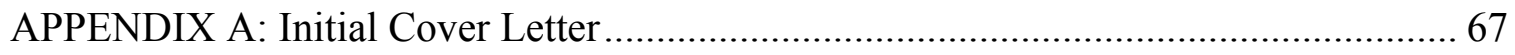



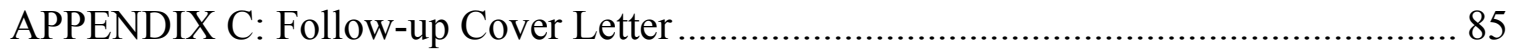

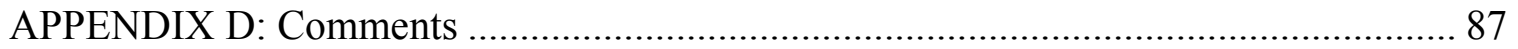

APPENDIX E: Open Ended Responses ...................................................... 91

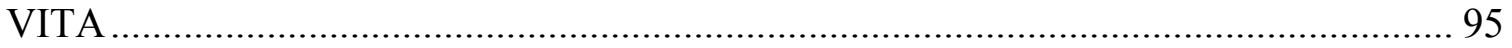




\section{LIST OF TABLES}

$\begin{array}{lll}\text { No Title Page } & \end{array}$

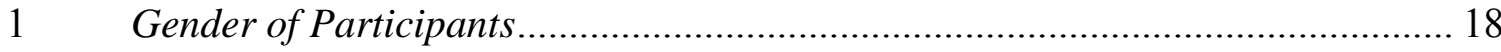

2 Years in Beef Cattle Business …………………........................................ 18

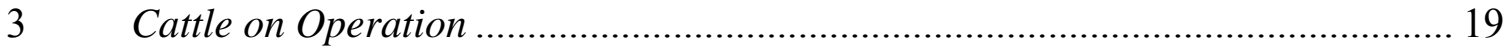

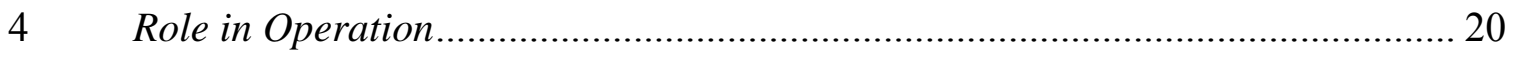

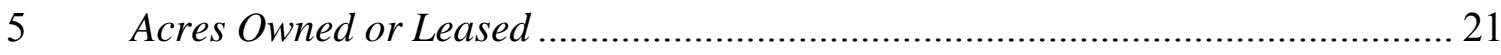

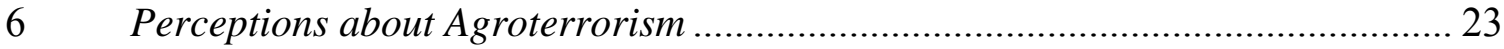

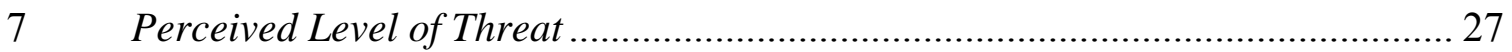

$8 \quad$ Attended Workshop on Biosecurity-Agroterrorism ............................................ 28

9 Where Producers would Seek Advice in Event of an Act of Agroterrorism.......... 29

$10 \quad$ Investments Made to Make Operation More Secure............................................ 30

11 Importance and Practicing of Safeguards on Farm ………................................ 38

$12 \quad$ Likelihood of Contacting Individual or Agency ................................................. 46

13 Access to Educational Material to Answer Beef Cattle Biosecurity Questions.... 49

14 Likelihood of Using Various Sources of Published Information ........................... 52

15 Extent of Outbreak Influences Decisions Towards Improving Security ............... 53

$16 \quad$ Attend Program about Agroterrorism-Biosecurity ……..................................... 54

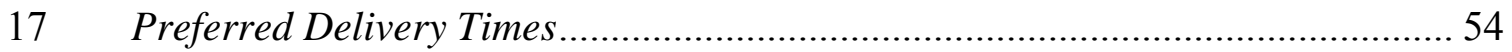

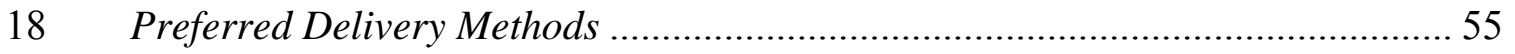

19 Participation in National Animal Identification .................................................. 56

$20 \quad$ Participation in Beef Quality Assurance Program (BQA) .................................. 57

$21 \quad$ Full-time and Part-time Employees of the Farm ………………....................... 57 


\section{CHAPTER I}

\section{Introduction}

The United States Department of Agriculture's Agricultural Research Service (USDA-ARS) estimates one in every eight persons works in some part of the agriculture/food sector (Schneider, Schneider, Webb, Hubbard, \& Archer, 2009). Agriculture and food production account for 13 percent of the United States gross domestic product (GDP), 18 percent of its employment, and 140 billion dollars in revenue (USDA, 2006). Agroterrorism is the deliberate introduction of detrimental agents, biological and otherwise, into the agricultural and food processing system with the intent of causing actual or perceived harm (Schneider, et al., 2009). An agroterrorism attack could affect many people throughout the world. However, a study by DeGraw (2005) found that many beef producers in Florida did not think it was necessary to be prepared for an agroterrorism attack.

Food production is one of the largest industries in the United States. If the food supply of America would be attacked, it would be hard for people to survive. Maintaining a safe food supply is a necessity. Contamination and adulteration of food for a target population could be an ideal target for terrorist attacks. Terrorists could attack the U.S. and no one would ever realize it until it had already made a huge impact on people. The international trade of agricultural goods is crucial to the U.S. (Schneider et al., 2009). If the agricultural industry in the U.S. is attacked, the financial losses would be devastating not only to producers in the U.S., but other countries as well.

Bioterrorism is defined as the use of a biological agent in a deliberate, harmful attack, or terrorism using the weapons of biological warfare such as anthrax, smallpox, or 
other pathogens (Schneider et al., 2009). Bioterrorism can target not only the agriculture industry, but also, the general population. The anthrax incident in the U.S. postal system after September 11 is an example of a bioterrorism attack (Schneider et al., 2009).

Awareness of food security in the United States was heightened after the September $11^{\text {th }}$ attack. On June 12, 2002, the Public Health Security and Bioterrorism Preparedness and Response Act of 2002 was signed in to law by Congress (Schneider et al., 2009). The Act was established to help prevent a bioterrorism attack on the food supply in the United States. The Food and Drug Administration is responsible for implementing regulations on food production and distribution (Schneider et al., 2009).

Consumer demand for beef declines during disease outbreaks in cattle which in turn impacts production. During an outbreak of Bovine Spongiform Encephalopathy (BSE) in the United States beef production declined for a couple of years (USDA, 2009). In $2008,26.56$ pounds of beef per person were produced in the United States (USDA, 2009). Decline in demand for beef could result from a number of factors, including changes in eating habits for health reasons or more vegans, and vegetarians (USDA, 2009).

Biosecurity procedures can help prevent farm visitors from carrying organisms on to farms and spreading diseases from farm to farm. Farm visitors can pose a risk for many reasons, including carrying pathogens from one farm to another. If a visitor has been out of the country; they pose an increased threat by carrying disease from foreign soil to a local farm. A biosecurity plan might include requiring visitors to change clothing and shoes, to disinfecting vehicles, and not having close contact with any animals (APHIS, 2007). For beef producers an effective biosecurity plan can make their cattle 
less susceptible to diseases, which could prevent loss of income. Preventative measures can keep cattle safe from diseases and other harmful organisms. Proper nutrition and management practices including a clean environment will reduce susceptibility to diseases (APHIS, 2007).

There are broadly based convictions that producers livelihoods and the public are best served by organizing, funding, and enforcing strict disease control guidelines through government intervention (Dargatz, \& Dargatz, 2002). Government agencies have mandated biosecurity plans for livestock producers. The aim of specific biosecurity programs is to combat specific health hazards on the farm such as BSE, Foot and Mouth Disease, Rabies, and Influenza (Valergakis, Aresenos, \& Konomou, 2008). However, the lack of direct or perceived incentives to adopting biosecurity technologies on beef cattle farms has resulted in few beef producers who are implementing recommended biosecurity practices.

Biosecurity includes prevention and security. Prevention is the most important and cost effective line of defense against harmful organisms (Meyerson, \& Reaser, 2002). Studies have found that producers are not following good management practices or implementing biosecurity plans (DeGraw, 2005). Failure to follow biosecurity recommendations poses a great risk of introducing diseases to the cattle herd. Management practices such as vaccinating on schedule and quarantining new animals brought on the farm can help prevent outside organisms from infecting the existing herds (Sanderson, Dargatz, \& Garry, 2000). 


\section{Problem Statement}

There are 10,653 beef producers in West Virginia. Unlike the poultry industry where biosecurity plans are required for each operation, beef producers are not required to have biosecurity plans. Are West Virginia beef producers aware of biosecurity practices and the impact the lack of biosecurity practices can have on their farms due to diseases and potential financial loss? What are West Virginia beef producers' perceptions of the potential for an agroterrorism attack and what biosecurity measures are they practicing?

\section{Purpose of the Study}

The purpose of the study was to determine West Virginia beef cattle producers' perceptions of their preparedness for an agroterrorism attack. Have they implemented biosecurity plans, and to what degree? What is West Virginia beef producers' level of knowledge about recommended biosecurity measures and where do they get their information regarding biosecurity practices?

\section{Objectives of the Study}

The following objectives were used to guide the research:

1. Identify West Virginia beef producers' preparedness for an agroterrorism attack.

2. Identify current biosecurity practices of West Virginia beef producers.

3. Identify West Virginia beef producers' perceptions of risk related to bioterrorism and agroterrorism.

4. Identify where West Virginia beef producers go for information on biosecurity.

5. Determine West Virginia beef producers' preferred delivery methods for receiving information on bioterrorism and agroterrorism. 


\section{CHAPTER II}

\section{Review of Literature}

Realization that food security could be an issue in the United States became more evident after the September 11, 2001 terrorism attack. After the attack more precautions and regulations were put into effect for many areas of the economy. Agriculture was more vulnerable to terrorists because it was one way to hurt mass numbers of people and the economy. Soon afterward the attack new rules and guidelines were developed to reduce the agriculture industry's vulnerability. On June 12, 2002, the Public Health Security and Bioterrorism Preparedness and Response Act of 2002 was signed in to law (Schneider, et. al, 2009). According to Schneider, Schneider, Webb, Hubbard, and Archer (2009) the U.S. has not been the victim of a large-scale, successful agroterrorism attack. The Act was designed to improve the ability of the U.S. to prevent, prepare for, and respond to bioterrorism and other public health emergencies (Schneider, et al, 2009). Kelly (2005) states that it seems obvious, that the need for adequate biosecurity measures on our farms should not be allowed to wait until agroterrorism becomes a reality.

Agroterrorism is the deliberate introduction of detrimental agents, biological and otherwise, into the agricultural and food processing system with the intent of causing actual or perceived harm (Schneider, et al., 2009). There are many broad areas of agriculture that can provide targets for an agroterrorism attack such as; livestock and farm animals, plant crops, food processing, distribution, and retailing.

Bioterrorism is defined as the use of a biological agent in a deliberate, harmful attack, or terrorism using the weapons of biological warfare such as anthrax, smallpox, or 
other pathogens (Schneider, et al., 2009). A bioterrorism attack can be directed at agriculture, the general public, domestic infrastructure or personnel.

Veterinary medicine has found that biosecurity measures can protect farms. The veterinary profession is presently challenged with developing and maintaining on-farm biosecurity protocols to protect the nation's food supply from acts of bioterrorism, from the growing threat of foreign animal disease, and from multidrug resistance among pathogenic organisms. Veterinarians have seen that farmers are resistant to implementing biosecurity practices until an agroterrorism attack becomes a reality. Veterinarians indicate that this is an issue and that farmers should not wait for an attack to occur (Kelly, 2005). The challenge comes at a time when the supply of food animal veterinarians in the U.S. is progressively in decline, and raises the possibility that the profession is not adequately prepared to fulfill its responsibilities to the health and productivity of the U.S. livestock and poultry populations (Kelly, 2005).

The United States Department of Agriculture (2006) stated that agriculture and food production accounts for thirteen percent of the United States' gross domestic product; eighteen percent of its employment; and one hundred and forty billion dollars in revenue. There is an increased awareness of the vulnerability of agriculture and food products to agroterrorism attacks. The United Sates Department of Agriculture (USDA) and Food and Drug Administration (FDA) are charged with ensuring the safety of America's food supply. It is their job to assure the American people that the food coming from the farm will remain safe until it reaches the consumer.

The goal of biosecurity is to stop the transmission of disease causing agents by preventing, minimizing or controlling cross-contamination of body fluids between 
animals, animals to feed and animals to equipment that may directly and indirectly contact animals (Buhman, Dewett, \& Griffin, 2007). Biosecurity is a sum of risk management practices as a defense against biological threats (Meyerson, \& Reaser, (2002).

The United States (U.S.) has identified as priorities, the protection of national systems and infrastructure such as the transportation, communication, water supply, and agriculture networks, to defend against terrorism. (Schneider, et al., 2009), but holes in prevention, preparedness, and response remain. Government agencies have been involved with most of the well-defined programs of biosecurity for livestock producers.

It is important for farmers to be able to get information on biosecurity and then to implement a biosecurity plan on their farm. While developing and maintaining biosecurity can be difficult, it is the cheapest, most effective means of disease control available, and no disease prevention program will work without it (Buhman, Dewett, \& Griffin, 2007). While it may not be possible for individuals to prevent a disease from arriving on our nation's shores, biosecurity practices can reduce the risk of introducing a disease onto a farm or spreading it to neighboring farms (APHIS, 2007).

Failure to follow biosecurity practices leaves farms unprotected and exposed to many potentially harmful things. On the farm, one of the greatest risks comes from bringing new animals onto the premises or comingling or exposing your animals to other animals. It is a common way to introduce new disease-causing organisms (APHIS, 2007). Some basic facts that would help farmers to limit biosecurity risks on their farms would be to understand the need to quarantine animals for at least 30 days when first brought on to a farm, not to use manure machinery for feeding, not to share equipment with other 
farmers, or allow farm visitors on the farm without proper preventive measures. To prevent potential hazards farmers should keep their animals healthy through proper nutrition and avoid stress to help build and keep their immunity. When vehicles enter a farm they should be disinfected, a farm should be kept clean, and one should be vigilant to prevent any potential risks. Farmers must also remember that wildlife can carry diseases that can infect livestock (APHIS, 2007).

According to the USDA in 2006, U.S. agriculture generated over \$1 trillion annually, including $\$ 50$ billion in exports. One in every eight Americans worked in some area of food production. One disease outbreak in the food production chain can cause food prices to go up. Even without agroterrorism, livestock and crop disease cost the U.S. economy billions of dollars annually (Schneider, et al, 2009). If an agroterrorism event occurred in the U.S. the potential for disruption to the export markets would be immense. International trade is crucial as it provides a market for a major part of our crop production, and growing share of meat output. Proportionately, the U.S. agriculture industries rely on export markets more heavily than other sectors of the U.S. economy. An agroterrorism event that instigated fear or even uncertainty in our international customers could be financially devastating to U.S. agriculture interests (Schneider, et al, 2009). The deliberate introduction of a pathogen into the U.S. livestock, poultry, or crops could cause a disease outbreak. Jayarao, Tewari, and Wolfgang (nd.) stated that the outcome of an outbreak could be devastating, resulting in the loss of livestock, disruption of animal agriculture industry and decreased food production. This would drive food prices up, halt valuable exports, and ultimately cost taxpayers billions of dollars in lost revenue and industry renewal costs. 
The recent terrorist attack on the U.S. raised serious concerns on the vulnerability of plant and animal agriculture in the U.S. As a result of the detection of only one case of Bovine Spongiform Encephalopathy (BSE) in the U.S. in December 2003, most countries banned U.S. beef causing the industry to lose between 3.2 and 4.7 billion dollars in 2004 . Two years later, Japan and South Korea, which together account for over 50 percent of beef exports, had not lifted the ban (DHS, 2005). On June 26, 2006 the ban was lifted off of the United States, and beef was once again exported to Japan (Clemens, 2007).

Experts warn that the American food supply system could be a target of a terrorist attack. While testifying before the Committee on Agriculture, Nutrition, and Forestry on July 20, 2005, Mr. John Lewis, Deputy Assistant Director, Counterterrorism Division, Federal Bureau of Investigation, stated, "Most people do not equate terrorist attacks with agroterrorism. But the threat is real, and the impact could have both severe public health and economic consequences, while damaging the public's confidence in the food we eat." (DHS, 2005).

According to a March 2005 Government Accountability Office (GAO) report entitled "Much is Being Done to Protect Agriculture from a Terrorist Attack, but Important Challenges Remain,” Department of Homeland Security's (DHS) communication with state and local officials and coordination of federal activities is lacking. The GAO reported a lack of communication between DHS and states regarding the development of emergency response plans, grant guidance, and best practices. State and industry officials reported that there is no mechanism to share lessons learned from exercises or real-life animal disease outbreaks. The GAO report also stated that shortcomings exist in the Department of Homeland Securities' federal coordination of 
national efforts to protect against agroterrorism. The lack of DHS leadership on agriculture security can be seen in the June 2004 incident in Washington State where 18 head of cattle developed chromium contamination. Agroterrorism was suspected, yet neither USDA nor DHS were notified for over a week (DHS, 2005).

In today's agriculture industries various trends are present that could potentially increase the spread and prevalence of infectious disease in cattle herds (Wolfgang, n.d.). The concern regarding infectious diseases spurred by the spread and economic devastation wrought by Foot and Mouth Disease in Britain, this is an excellent time to reinforce the need for a biosecurity program (Wolfgang, n.d.).

While biosecurity measures have historically benefited agriculture by reducing crop and livestock losses, as well as costs associated with control programs, there have also been benefits to human health and the environment through the reduced use of pesticides and the exclusion of some invasive alien species (Meyerson \& Reaser, 2002). Some of the policies and activities undertaken by USDA suggest that the department is willing and able to move toward a comprehensive biosecurity approach (Meyerson, \& Reaser, 2002).

The U.S. Department of Agriculture, Animal and Plant Health Inspection Service's and the Veterinary Service program maintains a high level of emergency preparedness, and provides the needed resources to respond to eliminate disease outbreaks in this country. In order to effectively protect against such outbreaks, it will take the help of veterinarians, livestock producers, as well as, state and local governments (APHIS, 2007). 


\section{Summary}

Realization that food security could be an issue in the United States became evident after the September 11, 2001 terrorism attack. The goal of biosecurity is to stop the transmission of disease causing agents by preventing, minimizing or controlling cross-contamination of body fluids between animals, animals to feed and animals to equipment that may directly and indirectly contact animals (Buhman, Dewett, \& Griffin, 2007). While developing and maintaining biosecurity is the cheapest, most effective means of disease control available, and no disease prevention program will work without

it (Buhman, Dewett, \& Griffin, 2007). Which raises the question of how do West Virginia beef producers perceive the risks and what preventive measures do they practice? 


\section{CHAPTER III}

\section{Methodology}

\section{Problem Statement}

There are 10,653 beef producers in West Virginia. Unlike the poultry industry where biosecurity plans are required for each operation, beef producers are not required to have biosecurity plans. Are West Virginia beef producers aware of biosecurity practices, and the impact the lack of biosecurity practices can have on their farms due to diseases and potential financial loss? What are West Virginia beef producers' perceptions of the potential for an agroterrorism attack and what biosecurity measures are they practicing?

\section{Purpose of the Study}

The purpose of the study was to determine West Virginia beef cattle producers' perceptions of their preparedness for an agroterrorism attack. Have they implemented biosecurity plans, and to what degree? What is West Virginia beef producers' level of knowledge about recommended biosecurity measures and where do they get their information regarding biosecurity practices?

\section{Objectives of the Study}

The following objectives were used to guide the research:

1. Identify West Virginia beef producers' preparedness for an agroterrorism attack.

2. Identify current biosecurity practices of West Virginia beef producers.

3. Identify West Virginia beef producers' perceptions of risk related to bioterrorism and agroterrorism.

4. Identify where West Virginia beef producers' go for information on biosecurity. 
5. Determine West Virginia beef producers' preferred delivery methods for receiving information on bioterrorism and agroterrorism.

\section{Research Design}

A descriptive research design using a mailed questionnaire was used to determine the perceptions of West Virginia beef cattle producers on their preparedness for an agroterrorism attack. A questionnaire was designed to determine what biosecurity practices are being implemented by beef producers in West Virginia. According to Ary, Jacobs, Razavieh, Sorensen (2006), surveys allow the researcher to measure the attitudes and opinions of the respondents to collect information from a sample of the target population.

\section{Population}

The target population of this study was all beef producers in West Virginia. Due to the lack of availability of an official list of beef producers for the state of West Virginia, the accessible population was selected from a compiled list of participants in the Southern Bull Test, Beef Quality Assurance Program, members on the West Virginia Cattleman's Association mailing list, participants in the South Branch and Weston livestock markets, and State Livestock Roundup ( $\mathrm{N}=4600)$. The Krejcie and Morgan guidelines (1960) were used to determine the total sample size of producers $(\mathrm{n}=355)$. A random sample of 355 producers was selected from the list.

\section{Instrumentation}

Mailed questionnaires were sent to 355 beef producers in West Virginia. The instrument had five parts and consisted of 78 questions. The first part of the questionnaire consisted of Likert-type questions designed to determine the producers' perceptions about 
agroterrorism. Each question had five available responses which were: strongly agree, agree, neither agree or disagree, disagree, and strongly disagree. The second part of the questionnaire was designed so the producers' could rate the level of perceived threat for various factors, the Likert-type responses included considerable, much, some, little, and none. The third section was designed to determine where producers would go to gather information on agroterrorism, using multiple choice questions. Part four was designed to assess the importance the producer put on selected safeguards and to what degree they practiced the safeguard. The responses provided for the "importance of the safeguard" included major, moderate, minor, and no importance. The responses for "degree to which you practice" were always, moderate, rarely, never, and not applicable. This section also sought to determine the likelihood of which individual/agency or published information source the producer would contact for additional information about agroterrorism livestock specific biosecurity threats. The responses provided included very likely, fairly likely, likely, unlikely, and very unlikely. Part five was designed to collect demographic information about the producer and their beef operation.

\section{Validity}

The instrument was presented to Livestock Extension Specialists and faculty members in the department of Agricultural and Extension Education at West Virginia University to establish its content and face validity. Each individual on the panel had extensive teaching or Extension experience. The panel determined that the instrument had content and face validity. 


\section{Reliability}

The reliability of the instrument was established using the final data set. Because the data consisted of nominal and ordinal scale responses, the Spearman Brown split half statistic was used to establish the instrument's reliability. The reliability was found to be exemplary with the coefficient of .758 (Robinson, Shaver, \& Wrightsman, 1991). The instrument was established as a reliable measure.

\section{Data Collection Procedures}

Dillman's Tailored Design Method (2007) was used to collect data for this study. A packet consisting of a cover letter (Appendix A), instrument (Appendix B), and a postage paid, self-addressed envelope was mailed to the participants on April 13, 2010 and was due back on April 28, 2010. A second packet was sent to all non-respondents on April 30, 2010. The second mailing consisted of another copy of the instrument, a followup cover letter (Appendix C), and a postage paid, self-addressed envelope. These individuals were given a deadline of May 17, 2010. A post card was sent to West Virginia beef producers that did not return a survey before May 17, 2010.

\section{Analysis of Data}

The data were entered into an Excel spreadsheet. The data were then transferred to SPSS for analysis, and the significance level was set a priori at $\leq .05$ for all statistical tests. Descriptive analyses were performed on the data and the appropriate methods of reporting each type of data were used.

\section{Use of Findings}

The findings from this study will be used to draw conclusions about the perceptions and preparedness of beef cattle producers in West Virginia with regard to 
agroterrorism and biosecurity. The information gathered will be shared with Extension personnel, University Animal Science faculty, the State Department of Agriculture and beef cattlemen's association to assist them in the development of educational materials and outreach programs on recommended biosecurity practices. 


\section{CHAPTER IV}

\section{Findings}

\section{Purpose of the Study}

The purpose of the study was to determine West Virginia beef cattle producers' perceptions of their preparedness for an agroterrorism attack. Have they implemented biosecurity plans, and to what degree? What is West Virginia beef producers' level of knowledge about recommended biosecurity measures and where do they get their information regarding biosecurity practices?

\section{Objectives of the Study}

The following objectives were used to guide the research:

1. Identify West Virginia beef producers' preparedness for an agroterrorism attack.

2. Identify current biosecurity practices of West Virginia beef producers.

3. Identify West Virginia beef producers' perceptions of risk related to bioterrorism and agroterrorism.

4. Identify where West Virginia beef producers go for information on biosecurity.

5. Determine West Virginia beef producers' preferred delivery methods for receiving information on bioterrorism and agroterrorism.

\section{Findings}

The target population for this study consisted of beef producers in West Virginia. The sample population of 355 was randomly selected. Out of the 355 surveys, 16 were returned as undeliverable, 5 were returned as deceased, and 7 producers were no longer farming making the sample population 327. Out of the 327 questionnaires 156 were returned for a response rate of $47.7 \%$. 


\section{Demographics}

One hundred and twenty-four $(87.3 \%)$ respondents were male while $18(12.7 \%)$ were female (see Table 1). One hundred and thirty-five $(95.1 \%)$ respondents had been in the beef cattle business for more than seven years. Two (1.4\%) beef producers indicated they had been in business for 73 months -7 years, one $(.7 \%)$ producer had been in business for 61 months -6 years, two (1.4\%) respondents had been in business for 49

months -5 years, while two $(1.4 \%)$ have only been in business for 37 months -4 years (see Table 2).

Table 1

Gender of Participants

\begin{tabular}{lcc}
\hline Gender & $\mathrm{N}$ & $\%$ \\
\hline Male & 124 & 87.3 \\
Female & 18 & 12.7 \\
\hline
\end{tabular}

Table 2

Years in Beef Cattle Business

\begin{tabular}{lcc}
\hline & $\mathrm{N}$ & $\%$ \\
\hline 37 months -4 years & 2 & 1.4 \\
49 months -5 years & 2 & 1.4 \\
61 months -6 years & 1 & .7 \\
73 months -7 years & 2 & 1.4 \\
More than 7 years & 135 & 95.1 \\
\hline
\end{tabular}




\section{Cattle on Operation}

Beef producers were asked the size of their beef cattle herd. Twenty-five (17.6\%) respondents had $1-20$ animals, $49(34.5 \%)$ had $21-50$ animals, and $40(28.2 \%)$ had $51-100$ animals. Thirteen $(9.2 \%)$ respondents had $101-200$ animals, $10(7.0 \%)$ had $201-300$ animals, three $(2.1 \%)$ had $301-500$ animals, and two (1.4\%) had 500 or more animals on their farm (see Table 3).

Table 3

Cattle on Operation

\begin{tabular}{lcc}
\hline & $\mathrm{N}$ & $\%$ \\
\hline $1-20$ animals & 25 & 17.6 \\
$21-50$ animals & 49 & 34.5 \\
$51-100$ animals & 40 & 28.2 \\
$101-200$ animals & 13 & 9.2 \\
$201-300$ animals & 10 & 7.0 \\
$301-500$ animals & 3 & 2.1 \\
$501+$ animals & 2 & 1.4 \\
\hline
\end{tabular}

\section{Role in Operation}

Beef producers were asked about their roles on their operations, $124(87.3 \%)$ respondents were owner-operators. Eleven (7.7\%) respondents indicated they were the operator on land they owned, two $(1.4 \%)$ indicated they were operators on rented-leased land, and five (3.5\%) indicated they had some other type of operation (see Table 4). 
Table 4

Role in Operation

\begin{tabular}{lcc}
\hline & $\mathrm{N}$ & $\%$ \\
\hline Owner-Operator & 124 & 87.3 \\
Operator on land you own & 11 & 7.7 \\
$\begin{array}{l}\text { Operator on rented-leased } \\
\text { land }\end{array}$ & 2 & 1.4 \\
Other & 5 & 3.5 \\
\hline
\end{tabular}

\section{Acreage Owned and/or Leased}

Respondents were asked about acres owned or leased. Five (3.5\%) beef producers indicated they did not own any land and 55 (39.3\%) indicated they did not lease any land. Forty-six (32.6\%) respondents owned land that was less than one acre to 99 acres, while $26(18.6 \%)$ leased land less than one acre to 99 acres (see Table 5).

Thirty-five (24.8\%) respondents owned $100-249$ acres and $23(16.4 \%)$ leased $100-249$ acres. Thirty (21.3\%) beef producers indicated they owned $250-499$ acres and $21(15 \%)$ leased $250-499$ acres. Seventeen (12.1\%) respondents owned $500-999$ and eight (5.7\%) leased 500 - 999 acres. Six (4.3\%) respondents indicated they owned $1000-1999$ and four $(2.9 \%)$ leased $1000-1999$. Two (1.4\%) owned 2000 or more acres and three (2.1\%) leased 2000 or more acres (see Table 5). 
Table 5

Acres Owned or Leased

\begin{tabular}{|c|c|c|c|c|}
\hline & \multicolumn{2}{|c|}{ Acres owned } & \multicolumn{2}{|c|}{ Acres leased } \\
\hline & $\mathrm{N}$ & $\%$ & $\mathrm{~N}$ & $\%$ \\
\hline None & 5 & 3.5 & 55 & 39.3 \\
\hline Less than 1 acre to 99 acres & 46 & 32.6 & 26 & 18.6 \\
\hline $100-249$ acres & 35 & 24.8 & 23 & 16.4 \\
\hline $250-499$ acres & 30 & 21.3 & 21 & 15.0 \\
\hline $500-999$ acres & 17 & 12.1 & 8 & 5.7 \\
\hline $1000-1999$ acres & 6 & 4.3 & 4 & 2.9 \\
\hline $2000-$ or more acres & 2 & 1.4 & 3 & 2.1 \\
\hline
\end{tabular}




\section{Perceptions and Preparedness for an Agroterrorism Attack}

Beef producers were asked to indicate their perceptions and preparedness of agroterrorism. Fifty-three respondents (39.3\%) strongly agree that agroterrorism could happen in the United States, and 70 (51.9\%) agreed. Eighty-one respondents $(60.0 \%)$ agreed that agroterrorism could happen in West Virginia and of the other respondents 18 $(13.3 \%)$ agreed. Twenty-seven respondents (20.5\%) agreed that an agroterrorism could happen on their farm, and five (3.8\%) strongly agreed (see Table 6).

Ten respondents $(7.4 \%)$ neither disagree nor agreed, and two (1.5\%) strongly disagreed that an agroterrorism attack could happen in the United States (U.S.). Twentythree respondents $(17.0 \%)$ neither disagreed nor agreed, nine $(6.7 \%)$ disagreed, and four (3.0\%) strongly disagreed that an agroterrorism attack could happen in West Virginia. Fifty-one (38.1\%) beef producers neither agreed nor disagreed that agroterrorism could happen on their farm, 35 (26.5\%) disagreed, and eight (6.1\%) strongly disagreed (see Table 6). 
Table 6

\section{Perceptions about Agroterrorism}

\begin{tabular}{|c|c|c|c|c|c|c|c|c|c|c|}
\hline & \multicolumn{2}{|c|}{ Strongly Disagree } & \multicolumn{2}{|c|}{ Disagree } & \multicolumn{2}{|c|}{$\begin{array}{l}\text { Neither Agree or } \\
\text { Disagree }\end{array}$} & \multicolumn{2}{|c|}{ Agree } & \multicolumn{2}{|c|}{ Strongly Agree } \\
\hline & $\mathrm{N}$ & $\%$ & $\mathrm{~N}$ & $\%$ & $\mathrm{~N}$ & $\%$ & $\mathrm{~N}$ & $\%$ & $\mathrm{~N}$ & $\%$ \\
\hline Agroterrorism in the USA & 2 & 1.5 & 0 & 0.0 & 10 & 7.4 & 70 & 51.9 & 53 & 39.3 \\
\hline Agroterrorism in West Virginia & 4 & 3.0 & 9 & 6.7 & 23 & 17.0 & 81 & 60.0 & 18 & 13.3 \\
\hline Agroterrorism on own farm & 20 & 14.9 & 27 & 20.1 & 51 & 38.1 & 34 & 25.4 & 2 & 1.5 \\
\hline $\begin{array}{l}\text { Preparedness for an agroterrorism } \\
\text { attack }\end{array}$ & 8 & 6.1 & 35 & 26.5 & 57 & 43.2 & 27 & 20.5 & 5 & 3.8 \\
\hline
\end{tabular}




\section{Perceived Threats to Farm}

West Virginia beef producers were asked to rate their level of perceived threat for several aspects of their farm. With regard to potential for water contamination, 46 $(33.6 \%)$ respondents indicated that water contamination was of little threat to them. Forty-six (33.6\%) producers indicated water contamination was some threat, $19(13.9 \%)$ considered it much of a threat, $18(13.1 \%)$ indicated it was a considerable threat, but 17 $(12.4 \%)$ beef producers said they did not feel that water contamination was a threat (see Table 7).

When asked about feed contamination, $47(34.3 \%)$ respondents indicated they perceived feed contamination somewhat of a threat to their farm, while $13(9.5 \%)$ perceived it to be much of a threat, and $11(8.0 \%)$ saw it as a considerable threat. Fortysix $(33.6 \%)$ respondents indicated that feed contamination was of little threat to their farm, while $20(14.6 \%)$ respondents considered feed contamination to be of no threat (see Table 7).

Sixty-five $(48.5 \%)$ beef producers indicated that the death of an animal was some threat on their farm, while, $15(11.2 \%)$ considered it much of a threat, and seven $(5.2 \%)$ reported animal death as a considerable threat to their farm. Thirty-two (23.9\%) respondents reported that animal death as of little threat, while, $15(11.2 \%)$ respondents considered animal death to be no threat on their farm (see Table 7).

Forty-nine (36.6\%) respondents indicated that an animal disease outbreak was some threat to their farm, while $22(16.4 \%)$ considered it much of a threat, and $12(9.2 \%)$ reported that an animal disease outbreak is a considerable threat to their farm. Thirty-six 
(26.9\%) respondents replied that an animal disease outbreak is of little threat, while, 15 (11.2\%) considered an animal disease outbreak to be no threat to their farm (see Table 7). Forty $(29.6 \%)$ beef producers felt that fertilizer theft misuse was of little threat to their farm, while 56 (41.5\%) felt that fertilizer theft misuse was of no threat. Twentyseven (20.0\%) indicated that fertilizer theft misuse was some threat, nine (6.7\%) considered it to be much threat, and three (2.2\%) reported that fertilizer theft misuse was a considerable threat (see Table 7).

Ninety-two (67.6\%) respondents reported that employee revenge was of no threat to their farm, $26(19.1 \%)$ considered it to be of little threat, and $10(7.4 \%)$ responded that employee revenge could be of some threat to their farm. Three (2.2\%) beef producers reported that employee revenge was a considerable threat to their farm, while, five (3.7\%) felt employee revenge was of much threat to their farm (see Table 7).

Thirty (22.2\%) respondents considered chemical contamination to be some threat to their farm, 10 (7.4\%) considered chemical contamination was of much threat, and 5 (3.7\%) reported it was a considerable threat. Fifty-four (40.0\%) replied that chemical contamination was of little threat, while, $36(26.7 \%)$ considered it to be of no threat to their farm (see Table 7).

When asked about Zoonotic illness, 32 (23.9\%) indicated they perceived Zoonotic illness as somewhat of a threat to their farm, while $55(41.0 \%)$ reported that Zoonotic illness was of little threat, and 35 (26.1\%) perceived it to be no threat. Seven (5.2\%) respondents indicated that Zoonotic illness was much of a threat to their farm, while 5 (3.7\%) felt it was a considerable threat (see Table 7). 
When respondents were asked about loss of income due to market loss, 35 (25.7\%) perceived it as a considerable threat, while $16(11.8 \%)$ reported it as no threat. Twentytwo $(16.2 \%)$ respondents reported that loss of income due to market loss was much of a threat, $34(25.0 \%)$ indicated it as somewhat of a threat, but $29(21.3 \%)$ considered it to be of little threat to their farm (see Table 7).

Thirty-four (25.2\%) respondents considered tampering with facilities somewhat of a threat to their farm, while $15(11.1 \%)$ perceived it was much of a threat, and 12 $(8.9 \%)$ indicated it was a considerable threat. Forty $(29.6 \%)$ respondents felt tampering with facilities was of little threat and $34(25.2 \%)$ did not feel that it was any threat at all (see Table 7).

Respondents were asked about the threat of people tampering with fences/gates, and $36(26.5 \%)$ responded it was somewhat of a threat to their farm. Twenty-seven $(19.9 \%)$ considered that the threat of tampering with fences/gates as much of a threat and $19(14.0 \%)$ felt it was a considerable threat. Twenty-nine $(21.3 \%)$ respondents indicated they felt tampering with fences/gates was of little threat to their farm, while, $25(18.4 \%)$ considered it no threat (see Table 7). 
Table 7

Perceived Level of Threat

\begin{tabular}{|c|c|c|c|c|c|c|c|c|c|c|}
\hline & \multicolumn{2}{|c|}{ None } & \multicolumn{2}{|c|}{ Little } & \multicolumn{2}{|c|}{ Some } & \multicolumn{2}{|c|}{ Much } & \multicolumn{2}{|c|}{ Considerable } \\
\hline & $\mathrm{N}$ & $\%$ & $\mathrm{~N}$ & $\%$ & $\mathrm{~N}$ & $\%$ & $\mathrm{~N}$ & $\%$ & $\mathrm{~N}$ & $\%$ \\
\hline Water contamination & 17 & 12.4 & 37 & 27.0 & 46 & 33.6 & 19 & 13.9 & 18 & 13.1 \\
\hline Feed contamination & 20 & 14.6 & 46 & 33.6 & 47 & 34.3 & 13 & 9.5 & 11 & 8.0 \\
\hline Animal death & 15 & 11.2 & 32 & 23.9 & 65 & 48.5 & 15 & 11.2 & 7 & 5.2 \\
\hline Animal disease outbreak & 15 & 11.2 & 36 & 26.9 & 49 & 36.6 & 22 & 16.4 & 12 & 9.0 \\
\hline Fertilizer theft-misuse & 56 & 41.5 & 40 & 29.6 & 27 & 20.0 & 9 & 6.7 & 3 & 2.2 \\
\hline Employee revenge & 92 & 67.6 & 26 & 19.1 & 10 & 7.4 & 5 & 3.7 & 3 & 2.2 \\
\hline Chemical contamination & 36 & 26.7 & 54 & 40.0 & 30 & 22.2 & 10 & 7.4 & 5 & 3.7 \\
\hline Zoonotic illness & 35 & 26.1 & 55 & 41.0 & 32 & 23.9 & 7 & 5.2 & 5 & 3.7 \\
\hline Loss of income due to market loss & 16 & 11.8 & 29 & 21.3 & 34 & 25.0 & 22 & 16.2 & 35 & 25.7 \\
\hline Tampering with facilities & 34 & 25.2 & 40 & 29.6 & 34 & 25.2 & 15 & 11.1 & 12 & 8.9 \\
\hline Tampering with fences-gates & 25 & 18.4 & 29 & 21.3 & 36 & 26.5 & 27 & 19.9 & 19 & 14.0 \\
\hline Other & 9 & 60.0 & 1 & 6.7 & 1 & 6.7 & 1 & 6.7 & 3 & 20.0 \\
\hline
\end{tabular}




\section{Attended Workshop on Biosecurity-Agroterrorism}

West Virginia beef producers were asked if they had ever attended a workshop on biosecurity-agroterrorism. Twenty-eight (20.6\%) beef producers said they have attended a biosecurity-agroterrorism workshop at least once, $11(8.1 \%)$ more than once, and 97 (71.3\%) reported they had never attended a workshop (see Table 8).

Table 8

Attended Workshop on Biosecurity-Agroterrorism

\begin{tabular}{lcc}
\hline & N & $\%$ \\
\hline Yes, at least once & 28 & 20.6 \\
More than once & 11 & 8.1 \\
No & 97 & 71.3 \\
\hline
\end{tabular}

\section{Where Producers would Seek Advice in Event of an Act of Agroterrorism}

Respondents were asked from whom they would seek advice if they suspected an act of agroterrorism had occurred on their farm. Seventy-one (51.1\%) respondents indicated they would contact a veterinarian, while, 59 (42.8\%) beef producers indicated they would call an Extension agent (see Table 7). The West Virginia Department of Agriculture (WVDA) was who 73 of the respondents (52.9\%) indicated they would call. Twenty-two (15.9\%) respondents indicated they would contact another livestock producer, while, $87(63.0 \%)$ respondents indicated they would contact law enforcement about an importance on agroterrorism attack. Seventeen (12.3\%) beef producers reported they would contact the United States Department of Agriculture (USDA) for advice on agroterrorism (see Table 9). 
Five (3.6\%) West Virginia beef producers would contact a producer association, while, six (4.3\%) would seek advice from state emergency management. Eleven $(8.0 \%)$ respondents reported they would contact the county emergency management for advice in agroterrorism, nine $(6.5 \%)$ respondents indicated they would seek advice from Homeland Security, while, eight (5.8\%) indicated they would not know who to contact for advice and two (1.4\%) respondents would contact someone else (see Table 9).

Table 9

Where Producers would Seek Advice in Event of an Act of Agroterrorism

\begin{tabular}{|c|c|c|c|c|}
\hline & \multicolumn{2}{|c|}{ No } & \multicolumn{2}{|c|}{ Yes } \\
\hline & $\mathrm{N}$ & $\%$ & $\mathrm{~N}$ & $\%$ \\
\hline Veterinarian & 68 & 48.9 & 71 & 51.1 \\
\hline Extension Agent & 79 & 57.2 & 59 & 42.8 \\
\hline WV Department of Agriculture & 65 & 47.1 & 73 & 52.9 \\
\hline Another livestock producer & 116 & 84.1 & 22 & 15.9 \\
\hline Law enforcement & 51 & 37.0 & 87 & 63.0 \\
\hline USDA & 121 & 87.7 & 17 & 12.3 \\
\hline Producer Association & 133 & 96.4 & 5 & 3.6 \\
\hline State Emergency Management & 132 & 95.7 & 6 & 4.3 \\
\hline $\begin{array}{l}\text { County Emergency } \\
\text { Management }\end{array}$ & 127 & 92.0 & 11 & 8.0 \\
\hline Homeland Security & 129 & 93.5 & 9 & 6.5 \\
\hline Don't know & 130 & 94.2 & 8 & 5.8 \\
\hline Other (please specify) & 136 & 98.6 & 2 & 1.4 \\
\hline
\end{tabular}


West Virginia beef producers were asked if they had made considerable investments since September 11, 2001 to make their operation more biosecure. Three (2.2\%) respondents indicated they have made considerable investments to make their operation more secure before September 11, 2001, 15 (11.0\%) made considerable investments after September 11, while, nine (6.6\%) indicated they made investments before and after September 11, 2001. One hundred and three (75.7\%) of the respondents indicated that the attack on the United States in September 2001 had no influence on their investments to make their operation more secure and six (4.4\%) did not know if they made any investments for security purposes since the September 2001 attack on the U.S (see Table 10).

Table 10

Investments Made to Make Operation More Secure

\begin{tabular}{lcc}
\hline & N & $\%$ \\
\hline Yes, before September 11, 2001 & 3 & 2.2 \\
Yes, before and after September 11, 2001 & 9 & 6.6 \\
Yes, after September 11, 2001 & 15 & 11.0 \\
No & 103 & 75.7 \\
Don't know & 6 & 4.4 \\
\hline
\end{tabular}

\section{Importance of Biosecurity Safeguards}

The participants were asked about the importance of a biosecurity safeguards and the degree to which each is practiced on their farm. Fourteen (11.0\%) respondents indicated limiting visitors was a safeguard of major important to their farm, $40(31.5 \%)$ responded limiting visitors was of moderate importance to their farm, and 51 (41.2\%) 
reported it was of minor importance, while $22(17.3 \%)$ respondents indicated that limiting visitors was of no importance to their farm. Eight (6.3\%) respondents reported they always practice limiting visitors on their farm, 29 (22.7\%) indicated they moderately practice limiting visitors, 39 (30.5\%) indicated they rarely practice limiting visitors, 36 (28.1\%) never practice limiting visitors, while, 16 (12.5\%) indicated that limiting visitors to their farm was not applicable (see Table 11).

Eleven $(8.8 \%)$ respondents indicated it was of major importance to require a waiting period for visitors from other farms, $32(25.6 \%)$ reported it was of moderate importance, and 45 (36.0\%) responded it was of minor importance. Thirty-seven (29.6\%) indicated that requiring a waiting period for visitors from other farms is of no importance. Six $(4.6 \%)$ respondents reported they always practice having a waiting period for visitors from other farms, 15 (11.5\%) indicated they moderately practice waiting periods, 30 (23.1\%) rarely practiced waiting periods, while, $56(43.1 \%)$ never practice waiting periods for visitors from other farms and $23(17.7 \%)$ indicated it was not applicable to their farm (see Table 11).

Sixty-nine (54.8\%) respondents indicated they feel it is of major importance to isolate a new animal before introducing it to an existing herd, 39 (31.0\%) respondents felt it was of moderate importance, and 10 (7.8\%) felt it was of minor importance. Eight (6.23\%) respondents felt it is of no importance to isolate new animals before introducing them to the existing herd. Sixty-four (49.2\%) beef producers reported they always practice isolating new animals before introducing them to the existing herd, $36(27.7 \%)$ moderately practice isolating new animals, $15(11.5 \%)$ rarely practice isolating new 
animals, and eight $(6.2 \%)$ never practice, while seven $(5.4 \%)$ indicated it was not applicable to their farm (see Table 11).

Seven $(5.8 \%)$ respondents indicated it is of major importance to require employees to wear overalls, $23(19.2 \%)$ respondents felt it was of moderate importance for employees to wear overalls, and $36(30.0 \%)$ felt it was of minor importance. Fiftyfour $(45.0 \%)$ respondents felt it was not important to require employees to wear overalls. Five $(3.9 \%)$ respondents indicated they always require employees to wear overalls, seven (5.4\%) respondents indicate they moderately require their employees to wear overalls, 18 $(14.0 \%)$ rarely require their employees to wear overalls, and $48(37.2 \%)$ never require their employees to wear overalls, while, 51 (39.5\%) felt it was not applicable to their farm (see Table 11).

Seven $(5.8 \%)$ respondents indicated it is of major importance for their employees to wear shoe covers, $27(22.5 \%)$ respondents indicate employees wearing shoe covers is of moderate importance, and $31(25.8 \%)$ felt it is of minor importance. Fifty-five $(45.8 \%)$ respondents felt it is of no importance to have employees wear shoe covers. Four $(3.1 \%)$ respondents reported they always practice making employees wear shoe covers, eight $(6.2 \%)$ respondents moderately practice, $14(10.8 \%)$ respondents indicated they rarely practice employees wearing shoe covers, and $52(40.0 \%)$ never have their employees wear shoe covers, while $52(40.0 \%)$ indicated it was not applicable to their farm (see Table 11).

Nine $(7.4 \%)$ respondents indicated it was of major importance to have visitors use a footbath, $26(21.3 \%)$ respondents indicated it was of moderate importance, and 41 $(33.6 \%)$ felt it was of minimal importance. Forty-six $(37.7 \%)$ respondents felt it was of 
no importance to require visitors to use footbaths. One $(.8 \%)$ respondent indicated they always require visitors to use footbaths, $5(3.9 \%)$ respondents moderately require footbaths, $13(10.2 \%)$ respondents rarely require footbaths, $73(57.0 \%)$ never require footbaths and $36(28.1 \%)$ felt using footbaths was not applicable to their farm (see Table 11).

Five $(4.2 \%)$ respondents indicated it was of major importance for employees to use footbaths, $22(18.6 \%)$ respondents indicated it was of moderate importance, and 37 $(31.4 \%)$ felt it was of minor importance for employees to use footbaths. Fifty-four $(45.8 \%)$ respondents felt it was of no importance to require employees to use footbaths. One $(.8 \%)$ respondent reported they always require employees to use footbaths, three $(2.3 \%)$ reported they moderately require employees to use footbaths, $11(8.6 \%)$ rarely require their employees to use footbaths, and 60 (46.9\%) indicated they never require employees to use footbaths, while, 53 (41.4\%) felt requiring employees to use footbaths was not applicable to their farm (see Table 11).

Five $(4.2 \%)$ respondents indicated it is of major importance that they require their visitors to wear gloves, $19(16.0 \%)$ respondents felt it was of moderate importance, and $39(32.8 \%)$ felt it is of minor importance. Fifty-six (47.1\%) respondents felt it is of no importance to require visitors to wear gloves. Two (1.6\%) respondents always require visitors to wear gloves, eight $(6.3 \%)$ respondents indicated they moderately require visitors to wear gloves, $15(11.9 \%)$ respondents rarely require visitors to wear gloves. Sixty-two respondents (49.2\%) never require visitors to wear gloves and $39(31.0 \%)$ felt requiring visitors to wear gloves is not applicable to their farm (see Table 11). 
Seven $(6.1 \%)$ respondents indicated it is of major importance for employees to wear gloves, $26(22.8 \%)$ indicated it is of moderate importance, and $34(29.8 \%)$ felt it is of minor importance. Forty-seven (41.2\%) respondents felt it is of no importance for employees to wear gloves. Three (2.3\%) respondents always require their employees to wear gloves, $18(14.1 \%)$ respondents moderately require their employees to wear gloves, $10(7.8 \%)$ respondents rarely require their employees to wear gloves, and $51(39.8 \%)$ never require gloves to be worn by their employees, while 46 (35.9\%) indicated requiring employees to wear gloves is not applicable to their farm (see Table 11).

Ten $(8.3 \%)$ respondents indicated it was of major importance to require visitors to stop at a biosecurity checkpoint before entering the farm, 21 (17.5\%) indicated it is of moderate importance and 26 (21.7\%) felt it was of minor importance to have visitors to stop at a biosecurity checkpoint when entering the farm. Sixty-three (52.5\%) respondents feel that it was of no importance for requiring visitor to stop at a biosecurity checkpoint when entering the farm. One (.8\%) respondent indicated they always have visitors to stop at a biosecurity checkpoint when entering the farm, four (3.2\%) respondents moderately require visitors to stop at a biosecurity checkpoint, nine (7.1\%) respondents indicated they rarely require visitors to stop at a biosecurity checkpoint, and 68 (54.0\%) never require visitors to stop at a biosecurity checkpoint when they enter the farm, while 44 (34.9\%) felt it was not applicable to their farm (see Table 11).

Two (1.7\%) respondents indicated it is of major importance to require people entering the farm to shower, seven (5.9\%) respondents indicated it was of moderate importance, and 27 (22.9\%) felt it was of minor importance. Eighty-two (69.5\%) respondents felt it was of no importance to have people shower before entering the farm. 
There were no respondents that felt they always or moderately required people to shower before entering their farm, four (3.2\%) respondents rarely required people to shower before entering the farm, while, $72(57.1 \%)$ never require people to shower before entering the farm, while 50 (39.7\%) felt it was not applicable to their farm (see Table 11).

Two $(1.7 \%)$ respondents indicated it is of major importance to require people to shower before leaving their farm, eight (6.7\%) respondents indicated it was of moderate importance, and 27 (22.7\%) indicated it is of minor importance to require people to shower before leaving the farm. Eighty-two (68.9\%) respondents felt it was of no importance for people to shower before leaving the farm (see Table 9). None of the respondents always require people to shower before leaving their farm, two (1.6\%) respondents moderately practice requiring people to shower before leaving their farm, three (2.4\%) rarely require showers before leaving and $71(56.8 \%)$ never require visitors to shower before leaving the farm, while 49 (39.2\%) indicated it was not applicable to their farm (see Table 11).

Seven $(6.0 \%)$ respondents indicated it is of major importance to require visitors to disinfect vehicles before entering the farm, $13(11.2 \%)$ respondents indicated it is of moderate importance, and $23(19.8 \%)$ indicated it was of minor importance. Seventythree $(62.9 \%)$ respondents felt it was of no importance for visitors to disinfect their vehicles before entering the farm. Three (2.4\%) respondents indicated they always require visitors to disinfect their vehicle, two $(1.6 \%)$ respondents indicated they moderately require visitors to disinfect their vehicle, seven (5.5\%) respondents rarely require visitors to disinfect their vehicles, and 67 (52.8\%) never require visitors to 
disinfect their vehicles, while, 48 (37.8\%) felt it was not applicable to their operation (see Table 11).

Nineteen $(17.3 \%)$ respondents indicated it is of major importance to conduct a background check on potential hires, $23(20.9 \%)$ respondents indicated it is of moderate importance, and $18(16.4 \%)$ felt it is of minor importance. Fifty $(45.5 \%)$ respondents indicated it is of no importance to require a background check on potential hires. Six (4.8\%) respondents indicated they always practice a background check on potential hires, $10(8.0 \%)$ respondents indicated they moderately required a background check, eight $(6.4 \%)$ respondents indicated they rarely perform background checks on potential hires, and $41(32.8 \%)$ never require a background check, while 60 (48.0\%) indicated background checks were not applicable to their farm (see Table 11).

Nineteen $(17.4 \%)$ respondents indicated it is of major importance they schedule regular meetings with their employees to determine their levels of satisfaction, $22(20.2 \%)$ respondents indicated it is of moderate importance, and $19(17.4 \%)$ felt it is of minor importance. Forty-nine (45.0\%) respondents indicated it was of no importance for regular schedule meeting to determine levels of satisfaction. Four $(3.2 \%)$ respondents indicated they always have meetings with their employees to determine levels of satisfaction, 14 $(11.1 \%)$ respondents moderately require scheduled meetings, $10(7.9 \%)$ respondents rarely require scheduled meetings to determine the levels of satisfaction, and $34(27.0 \%)$ never require scheduled meetings, while, 64 (50.8\%) indicated it was not applicable to their farm (see Table 11).

Twenty-five $(22.5 \%)$ respondents indicated it is of major importance to have a training program that will enable employees to quickly recognize or report a disease that 
happens on the farm, $31(27.9 \%)$ respondents indicated it is of moderate importance, and $15(13.5 \%)$ felt it was if minor importance. Forty (36.0\%) respondents indicated it is of no importance to have a training program that will enable employees to quickly recognize or report a disease that happens on the farm. Six (4.7\%) respondents indicated they always require a training program that will enable employees to quickly recognize or report a disease that happens on the farm, $24(18.9 \%)$ respondents moderately require training programs, $8(6.3 \%)$ respondents rarely require training programs for their employees, and $33(26.0 \%)$ never require trainings for their employees on recognizing and reporting a disease, while $56(44.1 \%)$ felt it was not applicable to their farm (see Table 11). 
Table 11

Importance and Practicing of Safeguards on Farm

\begin{tabular}{|c|c|c|c|c|c|c|c|c|c|c|c|c|c|c|c|c|c|c|}
\hline & \multicolumn{8}{|c|}{ Importance of the Safeguard } & \multicolumn{10}{|c|}{ Degree to Which Practiced } \\
\hline & \multicolumn{2}{|c|}{$\begin{array}{c}\text { No } \\
\text { Importance }\end{array}$} & \multicolumn{2}{|c|}{ Minor } & \multicolumn{2}{|c|}{ Moderate } & \multicolumn{2}{|c|}{ Major } & \multicolumn{2}{|c|}{$\begin{array}{c}\text { Not } \\
\text { Applicable }\end{array}$} & \multicolumn{2}{|c|}{ Never } & \multicolumn{2}{|c|}{ Rarely } & \multicolumn{2}{|c|}{ Moderate } & \multicolumn{2}{|c|}{ Always } \\
\hline & $\mathrm{N}$ & $\%$ & $\mathrm{~N}$ & $\%$ & $\mathrm{~N}$ & $\%$ & $\mathrm{~N}$ & $\%$ & $\mathrm{~N}$ & $\%$ & $\mathrm{~N}$ & $\%$ & $\mathrm{~N}$ & $\%$ & $\mathrm{~N}$ & $\%$ & $\mathrm{~N}$ & $\%$ \\
\hline Limiting visitors & 22 & 17.3 & 51 & 40.2 & 40 & 31.5 & 14 & 11.0 & 16 & 12.5 & 36 & 28.1 & 39 & 30.5 & 29 & 22.7 & 8 & 6.3 \\
\hline $\begin{array}{l}\text { Requiring a waiting } \\
\text { period for visitors }\end{array}$ & 37 & 29.6 & 45 & 36.0 & 32 & 25.6 & 11 & 8.8 & 23 & 17.7 & 56 & 43.1 & 30 & 23.1 & 15 & 11.5 & 6 & 4.6 \\
\hline Isolating a new & 8 & 6.3 & 10 & 7.9 & 39 & 31.0 & 69 & 54.8 & 7 & 5.4 & 8 & 6.2 & 15 & 11.5 & 36 & 27.7 & 64 & 49.2 \\
\hline $\begin{array}{l}\text { Requiring employees } \\
\text { to wear overalls }\end{array}$ & 54 & 45.0 & 36 & 30.0 & 23 & 19.2 & 7 & 5.8 & 51 & 39.5 & 48 & 37.2 & 18 & 14.0 & 7 & 5.4 & 5 & 3.9 \\
\hline $\begin{array}{l}\text { Requiring employees } \\
\text { to wear shoe covers }\end{array}$ & 55 & 45.8 & 31 & 25.8 & 27 & 22.5 & 7 & 5.8 & 52 & 40.0 & 52 & 40.0 & 14 & 10.8 & 8 & 6.2 & 4 & 3.1 \\
\hline $\begin{array}{l}\text { Requiring visitors to } \\
\text { use footbaths }\end{array}$ & 46 & 37.7 & 41 & 33.6 & 26 & 21.3 & 9 & 7.4 & 36 & 28.1 & 73 & 57.0 & 13 & 10.2 & 5 & 3.9 & 1 & .8 \\
\hline $\begin{array}{l}\text { Requiring employees } \\
\text { to use footbaths }\end{array}$ & 54 & 45.8 & 37 & 31.4 & 22 & 18.6 & 5 & 4.2 & 53 & 41.4 & 60 & 46.9 & 11 & 8.6 & 3 & 2.3 & 1 & .8 \\
\hline
\end{tabular}


Table 11 (Continued)

Importance and Practicing of Safeguards on Farm

\begin{tabular}{|c|c|c|c|c|c|c|c|c|c|c|c|c|c|c|c|c|c|c|}
\hline & \multicolumn{8}{|c|}{ Importance of the Safeguard } & \multicolumn{10}{|c|}{ Degree to Which Practiced } \\
\hline & \multicolumn{2}{|c|}{$\begin{array}{c}\text { No } \\
\text { Importance }\end{array}$} & \multicolumn{2}{|c|}{ Minor } & \multicolumn{2}{|c|}{ Moderate } & \multicolumn{2}{|c|}{ Major } & \multicolumn{2}{|c|}{$\begin{array}{c}\text { Not } \\
\text { Applicable }\end{array}$} & \multicolumn{2}{|c|}{ Never } & \multicolumn{2}{|c|}{ Rarely } & \multicolumn{2}{|c|}{ Moderate } & \multicolumn{2}{|c|}{ Always } \\
\hline & $\mathrm{N}$ & $\%$ & $\mathrm{~N}$ & $\%$ & $\mathrm{~N}$ & $\%$ & $\mathrm{~N}$ & $\%$ & $\mathrm{~N}$ & $\%$ & $\mathrm{~N}$ & $\%$ & $\mathrm{~N}$ & $\%$ & $\mathrm{~N}$ & $\%$ & $\mathrm{~N}$ & $\%$ \\
\hline $\begin{array}{l}\text { Requiring visitors to } \\
\text { stop at a biosecurity } \\
\text { checkpoint }\end{array}$ & 63 & 52.5 & 26 & 21.72 & & 17.5 & 10 & 8.34 & & 34.9 & 68 & 54.0 & 9 & 7.1 & 4 & 3.2 & 1 & .8 \\
\hline $\begin{array}{l}\text { Requiring visitors to } \\
\text { wear gloves }\end{array}$ & 56 & 47.1 & 39 & 32.81 & & 16.0 & 5 & 4.23 & & 31.0 & 62 & 49.21 & & 11.9 & 8 & 6.3 & 2 & 1.6 \\
\hline $\begin{array}{l}\text { Requiring employees } \\
\text { to wear gloves }\end{array}$ & 47 & 41.2 & 34 & 29.82 & & 22.8 & 7 & 6.14 & & 35.9 & 51 & 39.81 & 0 & 7.8 & 18 & 14.1 & 3 & 2.3 \\
\hline $\begin{array}{l}\text { Requiring people } \\
\text { entering the farm to } \\
\text { shower }\end{array}$ & 82 & 69.5 & 27 & 22.9 & 7 & 5.9 & 2 & 1.75 & & 39.7 & 72 & 57.1 & 4 & 3.2 & 0 & .0 & 0 & .0 \\
\hline $\begin{array}{l}\text { Requiring people } \\
\text { leaving the farm to } \\
\text { shower }\end{array}$ & 82 & 68.9 & 27 & 22.7 & 8 & 6.7 & 2 & 1.74 & & 39.2 & 71 & 56.8 & 3 & 2.4 & 2 & 1.6 & 0 & .0 \\
\hline $\begin{array}{l}\text { Requiring visitors to } \\
\text { disinfect vehicles }\end{array}$ & 73 & 62.9 & 23 & 19.81 & 3 & 11.2 & 7 & 6.04 & 48 & 37.8 & 67 & 52.8 & 7 & 5.5 & 2 & 1.6 & 3 & 2.4 \\
\hline
\end{tabular}


Table 11 (Continued)

Importance and Practicing of Safeguards on Farm

\begin{tabular}{|c|c|c|c|c|c|c|c|c|c|c|c|c|c|c|c|c|c|c|}
\hline & \multicolumn{8}{|c|}{ Importance of the Safeguard } & \multicolumn{10}{|c|}{ Degree to Which Practiced } \\
\hline & \multicolumn{2}{|c|}{$\begin{array}{c}\text { No } \\
\text { Importance }\end{array}$} & \multicolumn{2}{|c|}{ Minor } & \multicolumn{2}{|c|}{ Moderate } & \multicolumn{2}{|c|}{ Major } & \multicolumn{2}{|c|}{$\begin{array}{c}\text { Not } \\
\text { Applicable }\end{array}$} & \multicolumn{2}{|c|}{ Never } & \multicolumn{2}{|c|}{ Rarely } & \multicolumn{2}{|c|}{ Moderate } & \multicolumn{2}{|c|}{ Always } \\
\hline & $\mathrm{N}$ & $\%$ & $\mathrm{~N}$ & $\%$ & $\mathrm{~N}$ & $\%$ & $\mathrm{~N}$ & $\%$ & $\mathrm{~N}$ & $\%$ & $\mathrm{~N}$ & $\%$ & $\mathrm{~N}$ & $\%$ & $\mathrm{~N}$ & $\%$ & $\mathrm{~N}$ & $\%$ \\
\hline $\begin{array}{l}\text { Conducting } \\
\text { background checks } \\
\text { on potential hires }\end{array}$ & 50 & 45.5 & 18 & 16.4 & 23 & 20.9 & 19 & 17.3 & 60 & 48.0 & 41 & 32.8 & 8 & 6.4 & 10 & 8.0 & 6 & 4.8 \\
\hline $\begin{array}{l}\text { Have regular } \\
\text { meetings with } \\
\text { employees }\end{array}$ & 49 & 45.0 & 19 & 17.4 & 22 & 20.2 & 19 & 17.4 & 64 & 50.8 & 34 & 27.0 & 10 & 7.9 & 14 & 11.1 & 4 & 3.2 \\
\hline $\begin{array}{l}\text { Training program(s) } \\
\text { for employees to a } \\
\text { disease }\end{array}$ & 40 & 36.0 & 15 & 13.5 & 31 & 27.9 & 25 & 22.5 & 56 & 44.1 & 33 & 26.0 & 8 & 6.3 & 24 & 18.9 & 6 & 4.7 \\
\hline
\end{tabular}




\section{Likelihood Producer would Contact an Individual/Agency for Additional Information about Agroterrorism}

Respondents were asked what was the likelihood they would contact an individual/agency for additional information about agroterrorism, 59 (42.4\%) felt they would very likely contact a veterinarian. Twenty-three (16.5\%) respondents indicated it was fairly likely they would contact a veterinarian, $35(25.2 \%)$ were likely to contact a veterinarian, but $19(13.7 \%)$ respondents were unlikely to contact a veterinarian and three $(2.2 \%)$ beef producers reported they were very unlikely to contact a veterinarian for an agroterrorism information (see Table 12).

Fifty-nine (42.4\%) respondents felt they were very likely to contact an Extension agent, while, 23 (16.5\%) indicated they were fairly likely to contact an Extension agent. Thirty-five (22.2\%) respondents were likely to contact an Extension agent, 19 (13.7\%) indicated they were unlikely to contact Extension personnel, and nine (2.2\%) were very unlikely to contact an Extension agent (see Table 12).

Fifty-six (41.2\%) respondents indicated they would very likely contact the West Virginia Department of Agriculture (WVDA) for information on agroterrorism and biosecurity, while, 25 (18.4\%) respondents were fairly likely to contact the WVDA. Forty (29.4\%) respondents indicated they would likely contact WVDA, $10(7.4 \%)$ indicated they were unlikely to contact WVDA, and five (3.7\%) were very unlikely to contact WVDA (see Table 12).

Twenty-nine $(21.5 \%)$ respondents indicated they would very likely contact another livestock producer, while, $32(23.7 \%)$ respondents were fairly likely to contact another livestock producer. Forty-six (34.1\%) indicated they were likely to contact 
another livestock producer, while, 18 (13.3\%) respondents were unlikely to contact another livestock producer, and $10(7.4 \%)$ were very unlikely to contact another livestock producer (see Table 12).

Fifty $(36.8 \%)$ respondents indicated they would very likely to contact law enforcement for information on agroterrorism and biosecurity, while, 20 (14.7\%) respondents were fairly likely to contact law enforcement. Thirty-two $32(23.5 \%)$ respondents were likely to contact law enforcement, while, $20(14.7 \%)$ were unlikely to contact law enforcement, and $14(10.3 \%)$ were very unlikely to contact law enforcement (see Table 12).

Thirty-four (25.2\%) respondents indicated they would very likely contact the United Sates Department of Agriculture (USDA), while, 22 (16.3\%) respondents would fairly likely contact the USDA. Thirty-six (26.7\%) respondents were likely to contact the USDA, while, 31 (23.0\%) respondents were unlikely to contact USDA, and $12(8.9 \%)$ were very unlikely to contact USDA (see Table 12).

Thirteen (9.9\%) respondents indicated they were very likely to contact a producer association for information on agroterrorism and biosecurity, while, 15 (11.5\%) respondents were fairly likely to contact a producer association. Thirty-seven (28.2\%) respondents were likely to contact a producer association, while, $43(32.8 \%)$ respondents indicated they were unlikely to contact a producer association, and $23(17.6 \%)$ were very unlikely to contact a producer association (see Table 12).

Eleven (8.5\%) respondents indicated they were very likely to contact county and state emergency management, while, 17 (13.2\%) respondents were fairly likely to contact to county and state emergency management. Thirty-seven (28.7\%) respondents were 
likely to contact county and state emergency management, while, $41(31.8 \%)$ were unlikely to contact county and emergency management, and $23(17.8 \%)$ were very unlikely contact county and emergency management (see Table 12).

Eight $(6.0 \%)$ respondents were very likely to contact Homeland Security about agroterrorism and biosecurity, while, 14 (10.5\%) respondents indicated they were fairly likely to contact Homeland Security. Twenty-seven (20.3\%) respondents were likely to contact Homeland Security, while, 51(38.3\%) were unlikely to contact Homeland Security, and 33 (24.8\%) were very unlikely to contact Homeland Security (see Table 12).

Five $(3.8 \%)$ respondents indicated they would very likely contact state emergency management for information on agroterrorism and biosecurity, while, 13 (9.8\%) respondents indicated they were fairly likely. Thirty-five $(26.5 \%)$ respondents were likely to contact state emergency management, while, 49 (37.1\%) indicated they were unlikely to contact state emergency management, and $30(22.7 \%)$ were very unlikely to contact state emergency management (see Table 12).

Five $(3.8 \%)$ respondents indicated they were very likely to contact county emergency management for information on agroterrorism and biosecurity, while, 10 (7.6\%) respondents indicated they were fairly likely. Thirty-six (27.5\%) respondents indicated they were likely to contact county emergency management, while $50(38.2 \%)$ indicated they were unlikely, and $30(22.9 \%)$ were very unlikely to contact county emergency management (see Table 12).

Nine $(6.8 \%)$ respondents indicated they were very likely to contact Farm Bureau for information on agroterrorism and biosecurity, while, 19 (14.3\%) respondents were fairly likely to contact Farm Bureau. Forty-eight (36.1\%) respondents were likely to 
contact Farm Bureau, while, 31 (23.3\%) indicated they were unlikely, and 26 (19.5\%) were very unlikely to contact Farm Bureau (see Table 12).

Eleven $(8.3 \%)$ respondents indicated they were very likely to contact the West Virginia Beef Council (WVBC) for information on agroterrorism and biosecurity, while, $14(10.6 \%)$ respondents were fairly likely to contact WVBC. Thirty-four (25.8\%) respondents indicated they were likely to contact WVBC, while, 45 (34.1\%) indicated they were unlikely, and 28 (21.2\%) were unlikely to contact the WVBC (see Table 12).

Eighteen (13.3\%) respondents indicated they were very likely to contact the West Virginia Beef Cattle Association (WVBCA) for information on agroterrorism and biosecurity, while, 20 (14.8\%) respondents were fairly likely. Thirty-seven (27.4\%) respondents were likely to contact WVBCA, while, 38 (28.1\%) indicated they were unlikely, and $22(16.3 \%)$ were very unlikely to contact WVBCA (see Table 12).

Six (4.5\%) respondents indicated they were very likely to contact agriculture teachers for information on agroterrorism and biosecurity, while, six (4.5\%) respondents were fairly likely. Twenty-nine (21.6\%) respondents were likely to contact agriculture teachers, while, $60(44.8 \%)$ indicated they were fairly unlikely, and $33(24.6 \%)$ were very unlikely to contact agriculture teachers (see Table 12).

Thirteen (9.8\%) respondents indicated they were very likely to contact the West Virginia beef specialist for information on agroterrorism and biosecurity, while, 16 $(12.0 \%)$ respondents were fairly likely. Thirty-nine $(29.3 \%)$ respondents indicated they were likely to contact the WV beef specialist, while, 45 (33.8\%) indicated they were unlikely, and $20(15.0 \%)$ were very unlikely to contact the WV beef specialist (see Table 12). 
Eight $(6.0 \%)$ respondents indicated they were very likely to contact the West Virginia University Davis College of Agriculture, Natural Resources and Design for information on agroterrorism and biosecurity, while, $12(9.0 \%)$ respondents were fairly unlikely. Thirty-six (27.1\%) respondents were likely to contact the West Virginia University Davis College of Agriculture, Natural Resources and Design, while, 50 $(37.6 \%)$ indicated they were unlikely, and $27(20.3 \%)$ were very unlikely to contact the West Virginia University Davis College of Agriculture, Natural Resources and Design (see Table 12).

Four (3.0\%) respondents indicated they were very likely to contact Potomac State College (PSC) for information about agroterrorism and biosecurity, while, three (2.3\%) respondents were fairly likely to contact PSC. Seventeen (12.9\%) respondents were likely to contact PSC. Sixt-eight (51.5\%) indicated they were unlikely to contact PSC, and 40 (30.3\%) were very unlikely to contact PSC (see Table 12).

Six $(17.6 \%)$ respondents indicated they were not very likely to know who to contact about agroterrorism and biosecurity, while, two (5.9\%) respondents were fairly likely not to know who to contact. Seven (20.6\%) respondents indicated they were likely not to know who to contact, while, nine (26.5\%) indicated they were unlikely to know who to contact, and $10(29.4 \%)$ were very unlikely to know who to contact (see Table 12 ).

One $(14.3 \%)$ respondent indicated they were fairly likely to contact others about agroterrorism and biosecurity. One (14.3\%) respondent indicated they were likely to contact others, while, 5 (71.4\%) were very unlikely to contact others. Respondents felt they would also contact the stockyard (see Table 12). 
Table 12

Likelihood of Contacting Individual or Agency

\begin{tabular}{|c|c|c|c|c|c|c|c|c|c|c|}
\hline & \multicolumn{2}{|c|}{ Very Unlikely } & \multicolumn{2}{|c|}{ Unlikely } & \multicolumn{2}{|c|}{ Likely } & \multicolumn{2}{|c|}{ Fairly Likely } & \multicolumn{2}{|c|}{ Very Likely } \\
\hline & $\mathrm{N}$ & $\%$ & $\mathrm{~N}$ & $\%$ & $\mathrm{~N}$ & $\%$ & $\mathrm{~N}$ & $\%$ & $\mathrm{~N}$ & $\%$ \\
\hline Veterinarian & 3 & 2.2 & 19 & 13.7 & 35 & 25.2 & 23 & 16.5 & 59 & 42.4 \\
\hline Extension agent & 9 & 6.5 & 16 & 11.6 & 50 & 36.2 & 24 & 17.4 & 39 & 28.3 \\
\hline $\begin{array}{l}\text { West Virginia Dept. of } \\
\text { Agriculture }\end{array}$ & 5 & 3.7 & 10 & 7.4 & 40 & 29.4 & 25 & 18.4 & 56 & 41.2 \\
\hline $\begin{array}{l}\text { Another livestock } \\
\text { producer }\end{array}$ & 10 & 7.4 & 18 & 13.3 & 46 & 34.1 & 32 & 23.7 & 29 & 21.5 \\
\hline Law enforcement & 14 & 10.3 & 20 & 14.7 & 32 & 23.5 & 20 & 14.7 & 50 & 36.8 \\
\hline $\begin{array}{l}\text { United States } \\
\text { Department of } \\
\text { Agriculture }\end{array}$ & 12 & 8.9 & 31 & 23.0 & 36 & 26.7 & 22 & 16.3 & 34 & 25.2 \\
\hline Producer Association & 23 & 17.6 & 43 & 32.8 & 37 & 28.2 & 15 & 11.5 & 13 & 9.9 \\
\hline $\begin{array}{l}\text { State or County } \\
\text { Emergency }\end{array}$ & & & & & & & & & & \\
\hline Management & 23 & 17.8 & 41 & 31.8 & 37 & 28.7 & 17 & 13.2 & 11 & 8.5 \\
\hline
\end{tabular}


Table 12 (Continued)

Likelihood of Contacting Individual or Agency

\begin{tabular}{|c|c|c|c|c|c|c|c|c|c|c|}
\hline & \multicolumn{2}{|c|}{ Very Unlikely } & \multicolumn{2}{|c|}{ Unlikely } & \multicolumn{2}{|c|}{ Likely } & \multicolumn{2}{|c|}{ Fairly Likely } & \multicolumn{2}{|c|}{ Very Likely } \\
\hline & $\mathrm{N}$ & $\%$ & $\mathrm{~N}$ & $\%$ & $\mathrm{~N}$ & $\%$ & $\mathrm{~N}$ & $\%$ & $\mathrm{~N}$ & $\%$ \\
\hline Homeland Security & 33 & 24.8 & 51 & 38.3 & 27 & 20.3 & 14 & 10.5 & 8 & 6.0 \\
\hline $\begin{array}{l}\text { State Emergency } \\
\text { Management }\end{array}$ & 30 & 22.7 & 49 & 37.1 & 35 & 26.5 & 13 & 9.8 & 5 & 3.8 \\
\hline $\begin{array}{l}\text { County Emergency } \\
\text { Management }\end{array}$ & 30 & 22.9 & 50 & 38.2 & 36 & 27.5 & 10 & 7.6 & 5 & 3.8 \\
\hline Farm Bureau & 26 & 19.5 & 31 & 23.3 & 48 & 36.1 & 19 & 14.3 & 9 & 6.8 \\
\hline $\begin{array}{l}\text { West Virginia Beef } \\
\text { Council }\end{array}$ & 28 & 21.2 & 45 & 34.1 & 34 & 25.8 & 14 & 10.6 & 11 & 8.3 \\
\hline $\begin{array}{l}\text { West Virginia Beef } \\
\text { Cattleman's } \\
\text { Association }\end{array}$ & 22 & 16.3 & 38 & 28.1 & 37 & 27.4 & 20 & 14.8 & 18 & 13.3 \\
\hline Agriculture Teachers & 33 & 24.6 & 60 & 44.8 & 29 & 21.6 & 6 & 4.5 & 6 & 4.5 \\
\hline $\begin{array}{l}\text { West Virginia Beef } \\
\text { Specialist }\end{array}$ & 20 & 15.0 & 45 & 33.8 & 39 & 29.3 & 16 & 12.0 & 13 & 9.8 \\
\hline
\end{tabular}


Table 12 (Continued)

Likelihood of Contacting Individual or Agency

\begin{tabular}{|c|c|c|c|c|c|c|c|c|c|c|}
\hline & \multicolumn{2}{|c|}{ Very Unlikely } & \multicolumn{2}{|c|}{ Unlikely } & \multicolumn{2}{|c|}{ Likely } & \multicolumn{2}{|c|}{ Fairly Likely } & \multicolumn{2}{|c|}{ Very Likely } \\
\hline & $\mathrm{N}$ & $\%$ & $\mathrm{~N}$ & $\%$ & $\mathrm{~N}$ & $\%$ & $\mathrm{~N}$ & $\%$ & $\mathrm{~N}$ & $\%$ \\
\hline West Virginia & & & & & & & & & & \\
\hline University & 27 & 20.3 & 50 & 37.6 & 36 & 27.1 & 12 & 9.0 & 8 & 6.0 \\
\hline Potomac State College & 40 & 30.3 & 68 & 51.5 & 17 & 12.9 & 3 & 2.3 & 4 & 3.0 \\
\hline $\begin{array}{l}\text { Don't know who I } \\
\text { would contact }\end{array}$ & 10 & 29.4 & 9 & 26.5 & 7 & 20.6 & 2 & 5.9 & 6 & 17.6 \\
\hline Other, please specify & 5 & 71.4 & 0 & .0 & 1 & 14.3 & 1 & 14.3 & 0 & .0 \\
\hline
\end{tabular}




\section{Access to Education Material to Answer Beef Cattle Biosecurity Questions}

Respondents were asked if they had access to educational materials which could be used in answering their beef cattle biosecurity questions. Thirty-four (25.8\%) responded that they would have access to education materials, $70(53.0 \%)$ indicated they would not have access to any educational materials to help answer their beef cattle biosecurity questions, while, $28(21.2 \%)$ reported they did not know whether they would have access to educational materials or not (see Table 13).

Table 13

Access to Educational Material to Answer Beef Cattle Biosecurity Questions

\begin{tabular}{lcc}
\hline & $\mathrm{N}$ & $\%$ \\
\hline Yes & 34 & 25.8 \\
No & 70 & 53.0 \\
Don't Know & 28 & 21.2 \\
\hline
\end{tabular}

\section{Use of Published Sources for Additional Information about Agroterrorism}

Respondents were asked to indicate the likelihood of using various published sources for information about agroterrorism and biosecurity. Fifty $(36.2 \%)$ respondents indicated they were very likely to use a farm magazine for information on agroterrorism and biosecurity, 26 (18.8\%) respondents were fairly likely, and $45(32.6 \%)$ indicated they were likely to use a farm magazine for information, while, $11(8.0 \%)$ were unlikely, and six $(4.3 \%)$ were very unlikely to use a farm magazine for information (see Table 14$)$.

Twenty-seven $(20.0 \%)$ respondents indicated they were very likely to read a newspaper for information on agroterrorism and biosecurity, while, 24 (17.8\%) would 
fairly likely read a newspaper. Forty-two (31.1\%) respondents indicated they were likely to read a newspaper for information on agroterrorism, while, $30(22.2 \%)$ indicated they were unlikely, and $12(8.9 \%)$ were very unlikely to read a newspaper for information on agroterrorism (see Table 14).

Twenty-six (19.4\%) respondents indicated they were very likely to use the Internet to find information on agroterrorism and biosecurity, while, 28 (20.9\%) respondents indicated they were fairly likely. Thirty (22.4\%) were likely, while, 19 $(14.2 \%)$ indicated they were unlikely, and $31(23.1 \%)$ were very unlikely to use the Internet to find information on agroterrorism and biosecurity (see Table 14).

Two (1.5\%) respondents indicated they would very likely read published library material to gain knowledge on agroterrorism and biosecurity, while, nine $(6.8 \%)$ respondents indicated they would fairly likely read library materials. Twenty-three (17.4\%) would likely read published library materials; while, 58 (43.9\%) respondents were unlikely, and $40(30.3 \%)$ were very unlikely to read published library materials to gain knowledge on agroterrorism and biosecurity (see Table 14).

Forty-four (32.8\%) respondents indicate they would very likely go to the Extension office to get published materials on agroterrorism and biosecurity, while, 16 (11.9\%) respondents were fairly likely to go the Extension office. Forty-four (32.8\%) indicated they were likely to go to the Extension office, while, 21 (15.7\%) indicated they were unlikely, and nine (6.7\%) very unlikely go to the Extension office to get published materials on agroterrorism and biosecurity (see Table 14).

Thirty-two (23.9\%) respondents indicated they were very likely to go to West Virginia University (WVU) for published materials on agroterrorism and biosecurity, 
while, $23(17.2 \%)$ respondents were fairly likely to contact West Virginia University (WVU). Thirty-nine (29.1\%) respondents were likely to go to West Virginia University (WVU) for published materials on agroterrorism and biosecurity, while, 29 (21.6\%) indicated they were unlikely to contact WVU, and $11(8.2 \%)$ very unlikely to go to West Virginia University (WVU) for published materials on agroterrorism and biosecurity (see Table 14).

Five (45.5\%) respondents felt they would very likely find other published material on agroterrorism and biosecurity, one (9.1\%) felt they were likely to find other materials, and five (45.5\%) reported it was very unlikely they would find other materials. Other published materials respondents felt they would find would be news on television, veterinarian, VPI, NCBA, RCALF, USDA, WV Farm Bureau, Market Bulletin, and WVDA (see Table 14). 
Table 14

Likelihood of Using Various Sources of Published Information

\begin{tabular}{|c|c|c|c|c|c|c|c|c|c|c|}
\hline & \multicolumn{2}{|c|}{ Very Unlikely } & \multicolumn{2}{|c|}{ Unlikely } & \multicolumn{2}{|c|}{ Likely } & \multicolumn{2}{|c|}{ Fairly Likely } & \multicolumn{2}{|c|}{ Very Likely } \\
\hline & $\mathrm{N}$ & $\%$ & $\mathrm{~N}$ & $\%$ & $\mathrm{~N}$ & $\%$ & $\mathrm{~N}$ & $\%$ & $\mathrm{~N}$ & $\%$ \\
\hline Farm Magazine & 6 & 4.3 & 11 & 8.0 & 45 & 32.6 & 26 & 18.8 & 50 & 36.2 \\
\hline Newspaper & 12 & 8.9 & 30 & 22.2 & 42 & 31.1 & 24 & 17.8 & 27 & 20.0 \\
\hline $\begin{array}{l}\text { Internet (World Wide } \\
\text { Web) }\end{array}$ & 31 & 23.1 & 19 & 14.2 & 30 & 22.4 & 28 & 20.9 & 26 & 19.4 \\
\hline Library Publications & 40 & 30.3 & 58 & 43.9 & 23 & 17.4 & 9 & 6.8 & 2 & 1.5 \\
\hline Extension Office & 9 & 6.7 & 21 & 15.7 & 44 & 32.8 & 16 & 11.9 & 44 & 32.8 \\
\hline $\begin{array}{l}\text { West Virginia } \\
\text { University }\end{array}$ & 11 & 8.2 & 29 & 21.6 & 39 & 29.1 & 23 & 17.2 & 32 & 23.9 \\
\hline Other, please specify: & 5 & 45.5 & 0 & .0 & 1 & 9.1 & 0 & .0 & 5 & 45.5 \\
\hline
\end{tabular}




\section{Impact of Disease Outbreaks}

Beef producers were asked whether or not the Foot and Mouth Disease outbreak in England and Bovine Spongiform Encephalopathy (BSE) outbreak in the U.S. had any influence on them improving security on their farm. Seven $(5.2 \%)$ respondents indicated that the outbreaks had a strong influence on making their farm more secure, while 20 (14.9\%) felt the outbreaks had no influence on their current biosecurity practices. Thirtysix $(26.9 \%)$ beef producers indicated that the outbreaks influenced their decision on making their operations more secure, but 19 (14.2\%) felt the outbreaks had minimal influence on their operation. Fifty-two $(38.8 \%)$ respondents indicated the outbreaks neither strongly influenced nor minimally influenced their decisions to make their operation more secure (see Table 15).

Table 15

Extent of Outbreak Influences Decisions Towards Improving Security

\begin{tabular}{lcc}
\hline & $\mathrm{N}$ & $\%$ \\
\hline Strongly Influenced & 7 & 5.2 \\
Influenced & 36 & 26.9 \\
Neither & 52 & 38.8 \\
Minimal Influence & 19 & 14.2 \\
No Influence & 20 & 14.9 \\
\hline
\end{tabular}

\section{Program Expectations}

Beef producers in West Virginia were asked if they would attend a program about agroterrorism-biosecurity. Seventy-seven (54.6\%) respondents replied that they would attend a program, $17(12.1 \%)$ indicated they would not attend a program on 
agroterrorism-biosecurity, while, 47 (33.3\%) were not sure whether or not they would attend a program (see Table 16).

Table 16

Attend Program about Agroterrorism-Biosecurity

\begin{tabular}{lcc}
\hline & N & $\%$ \\
\hline Yes & 77 & 54.6 \\
No & 17 & 12.1 \\
Not Sure & 47 & 33.3 \\
\hline
\end{tabular}

Respondents were asked when they would prefer an educational program on agroterrorism and biosecurity be offered. Ninety-six (78.0\%) respondents preferred evenings for a meeting, $16(13.0 \%)$ respondents preferred weekends, and $11(8.9 \%)$ indicated they would attend meetings offered weekdays (see Table 17).

Table 17

Preferred Delivery Times

\begin{tabular}{lcc}
\hline & $\mathrm{N}$ & $\%$ \\
\hline Weekends & 16 & 13.0 \\
Evenings & 96 & 78.0 \\
Weekdays & 11 & 8.9 \\
\hline
\end{tabular}

Respondents were asked what delivery method they would prefer be used in delivering information on agroterrorism and biosecurity. Sixty-eight (47.6\%) respondents indicated they preferred to go to dinner meetings, 61 (42.7\%) respondents preferred 
printed materials they could read on their own, and $54(37.8 \%)$ indicated they would like to go to trainings (see Table 18).

Table 18

Preferred Delivery Methods

\begin{tabular}{lcc}
\hline & $\mathrm{N}$ & $\%$ \\
\hline Dinner meetings & 68 & 47.6 \\
Read printed materials at your own pace & 61 & 42.7 \\
Trainings & 54 & 37.8 \\
Demonstrations & 43 & 30.1 \\
Lectures & 30 & 21.0 \\
Video-DVD & 27 & 18.9 \\
Fact sheet & 25 & 17.5 \\
One-on-One contact & 21 & 14.7 \\
Books & 15 & 10.5 \\
Take classes on the Internet & 13 & 9.1 \\
Group work & 12 & 8.4 \\
Computer software & 8 & 5.6 \\
Audio cassettes-CDs & 5 & 3.5 \\
\hline
\end{tabular}

Forty-three (30.1\%) respondents preferred to watch demonstrations, $30(21.0 \%)$ indicated a preference for lectures, 27 (18.9\%) preferred video-dvds, and 25 (17.5\%) indicated they would like fact sheets to read. Twenty-one $(14.7 \%)$ respondents indicated they would prefer one-on-one contact, 15 (10.5\%) indicated a preference for reading books, and $13(9.1 \%)$ indicated they would prefer to take classes on the Internet. Twelve 
(8.4\%) respondents felt they would like group work settings, eight (5.6\%) preferred computer software, while, five (3.5\%) preferred to listen to audio cassette tapes-cd's (see Table 18).

\section{National Animal Identification}

Beef producers in West Virginia were asked if their farm was registered in the animal identification system. Ninety $(65.2 \%)$ respondents were registered in the national animal identification system, 33 (23.9\%) were not registered, while, 15 (10.9\%) were not sure (see Table 19).

Table 19

Participation in National Animal Identification

\begin{tabular}{lcc}
\hline & $\mathrm{N}$ & $\%$ \\
\hline Yes & 90 & 65.2 \\
No & 33 & 23.9 \\
Not sure & 15 & 10.9 \\
\hline
\end{tabular}

Respondents were asked if they had been through the Beef Quality Assurance (BQA) program. Forty-seven (34.1\%) had been through the BQA program, 67 (48.6\%) had not been through the program, and $24(17.4 \%)$ were not sure if they had gone through the program (see Table 20). 
Table 20

Participation in Beef Quality Assurance Program (BQA)

\begin{tabular}{lll}
\hline & N & $\%$ \\
\hline Yes & 47 & 34.1 \\
No & 67 & 48.6 \\
Not sure & 24 & 17.4 \\
\hline
\end{tabular}

Respondents were asked how many employees they employed full-time and parttime in their operation. One hundred and twenty-nine (91.5\%) respondents reported they did not have any full-time employees, while, $84(61.8 \%)$ did not have any part-time employees. Nine (6.4\%) respondents had $1-2$ full-time employees and $46(33.8 \%)$ had1 - 2 part-time employees. One (.7\%) had 3 - 4 fill-time employees and five (3.7\%) had 3 4 part-time employees. Two (1.4\%) respondents had more than four full-time employees, and one (.7\%) had more than four part-time employees (see Table 21 ).

Table 21

Full-time and Part-time Employees of the Farm

\begin{tabular}{lcrcc}
\hline & \multicolumn{2}{c}{ Full-time employees } & \multicolumn{2}{c}{ Part-time employees } \\
\cline { 2 - 5 } & $\mathrm{N}$ & $\%$ & $\mathrm{~N}$ & $\%$ \\
\hline None & 129 & 91.5 & 84 & 61.8 \\
$1-2$ & 9 & 6.4 & 46 & 33.8 \\
$3-4$ & 1 & .7 & 5 & 3.7 \\
More than 4 & 2 & 1.4 & 1 & .7 \\
\hline
\end{tabular}




\section{CHAPTER V}

\section{Summary, Discussion, Conclusions, and Recommendations}

\section{Purpose of the Study}

The purpose of the study was to determine West Virginia beef cattle producers' perceptions of their preparedness for an agroterrorism attack. Have they implemented biosecurity plans, and to what degree? What is West Virginia beef producers' level of knowledge about recommended biosecurity measures and where do they get their information regarding biosecurity practices?

\section{Objectives of the Study}

The following objectives were used to guide the research:

1. Identify West Virginia beef producers' preparedness for an agroterrorism attack.

2. Identify current biosecurity practices of West Virginia beef producers.

3. Identify West Virginia beef producers' perceptions of risk related to bioterrorism and agroterrorism.

4. Identify where West Virginia beef producers go for information on biosecurity.

5. Determine West Virginia beef producers' preferred delivery methods for receiving information on bioterrorism and agroterrorism.

\section{Summary}

Three hundred and fifty-five participants were randomly selected from participants in the Southern Bull test, Beef Quality Assurance, The West Virginia Cattleman's Association, two livestock markets (Weston and South Branch), and the State Livestock Roundup. Mailed questionnaires were sent to the producers, 156 surveys out of 355 beef were returned for a response rate of $(47.7 \%)$. 
Research Objective One - "Identify West Virginia beef producers' preparedness for an agroterrorism attack."

The majority of the respondents were uncertain if they were prepared for an agroterrorism attack. Most West Virginia beef producers (75\%) felt they did not make any considerable investments to make their operations more secure after September 11, 2001. Beef producers also indicated the previous outbreaks of Foot and Mouth Disease and Bovine Spongiform Encephalopathy had no influence or little influence on their biosecurity measures.

Research Objective Two - "Identify current biosecurity practices of West Virginia beef producers.”

Most of the West Virginia beef producers agreed that isolating new animals before introducing them to the existing herd is of major importance in keeping their farm safe. The majority also indicated they always practice isolating new animals. The beef producers also agreed that participation in training programs would enable employees to quickly report and recognize a disease.

Research Objective Three - "Identify West Virginia beef producers' perceptions of risk related to bioterrorism and agroterrorism."

A majority of West Virginia beef producers agreed that an agroterrorism attack could happen in the United States and in the state of West Virginia, but they were uncertain if it would happen on their own farm. West Virginia beef producers were also uncertain on their preparedness for an agroterrorism attack.

The majority of West Virginia beef producers rated loss of income due to market loss as a considerable threat. The next most popular perceived threat was people 
tampering with the gates and fences. A majority of the farmers did not perceive employee revenge as a threat.

Research Objective Four - "Identify where West Virginia beef producers go for information on biosecurity.”

Beef producers in West Virginia indicated they would most likely contact law enforcement if they suspected an act of agroterrorism. The next individual or agency a beef producer would contact was the West Department of Agriculture (WVDA), followed by a veterinarian. The majority of the beef producers were very likely to contact all three of these agencies or individuals.

A majority of the West Virginia beef producers indicated they would very likely read a farm magazine to learn information about agroterrorism and biosecurity. The next most popular means to gather information would be to contact an Extension agent, followed by contacting West Virginia University (WVU). Research Objective Five - "Determine West Virginia beef producers' preferred delivery methods for receiving information on agroterrorism."

West Virginia beef producers indicated they would most likely attend evening meetings for information on agroterrorism, preferably a dinner meeting, followed by weekend meetings. The beef producers also indicated a preference to read materials at their own pace, and to attend trainings on agroterrorism and biosecurity.

\section{Discussion}

The results in West Virginia confirm the findings by DeGraw (2005) who found Florida beef producers also have not attended biosecurity workshops. Beef producers in West Virginia, like those in Florida, have not made considerable investments regarding 
security on their operations following the terrorist attacks in the U.S. on September 11, 2001, or following Foot and Mouth Disease and BSE outbreaks. Beef producers in West Virginia and Florida both indicated they would contact law enforcement if they suspected an agroterrorism attack on their farm.

West Virginia beef producers indicated that the most important safeguard and the safeguard most widely practiced on their operation was isolating new animals before introducing them to the existing herd. While DeGraw (2005), found that Florida beef producers indicated that limiting visitors was their most important safeguard and the one safeguard most frequently practiced, while isolating a new animal was second most popular safeguard.

Other similarities between this study and the DeGraw study found that both West Virginia and Florida beef producers agreed that an act of agroterrorism could happen in the U.S. and could happen on their operation. West Virginia producers indicated they were neutral on whether or not they are prepared for an agroterrorism attack to happen on their operation, while DeGraw (2005) reported Florida producers do not feel they are prepared for an agroterrorism attack to happen on their operation.

When sources of information about biosecurity were explored West Virginia beef producers indicated they would contact a veterinarian about biosecurity questions, while DeGraw found beef producers in Florida would contact the University of Florida. However, this study confirms the findings by DeGraw (2004) that beef producers would look in a farm magazine for published information on biosecurity. When asked about when they prefer trainings, West Virginia producers' preferred evening, dinner meetings, 
while DeGraw reports that Florida producers prefer weekend trainings, indicating both do not desire week-day programs.

This study confirmed many of the findings of DeGraw (2005), even though the average herd size between the two states varies greatly. West Virginia producers indicating they have 21-50 animals on their operation, whereas DeGraw reported Florida producers had 1,000 or more animals on their operation. The difference in herd size does not seem to impact beef producers lack of perceived preparedness for a biosecurity attack on their farm. Herd size may be more of an indicator of the producers' perceived threats. West Virginia producers with smaller herd sizes, consider loss of income due to market loss as a considerable threat. However, DeGraw found those producers in Florida where the average herd was 1,000 head; felt that an animal disease outbreak was much of a threat to their operation.

\section{Conclusions}

Based on the results of the study, the following conclusions were made

1. West Virginia beef producers agree that an agroterrorism attack could happen in the United States.

2. The majority of West Virginia beef producers always practice isolating new animals before introducing them to the existing herd.

3. The majority of West Virginia beef producers have never attended a workshop on biosecurity-agroterrorism.

4. West Virginia beef producers would most likely contact law enforcement for advice about agroterrorism. 
5. West Virginia beef producers have not made considerable investments to make their operations more secure.

6. West Virginia beef producers would prefer a farm magazine to read for published information about agroterrorism and biosecurity.

7. West Virginia beef producers prefer evening trainings, preferably with dinner as a method to learn about agroterrorism and biosecurity.

8. A majority of West Virginia beef producers indicate they would attend a program on agroterrorism and biosecurity.

\section{Recommendations}

The researcher makes the following recommendations based on the results of this study:

1. Evening/dinner training programs to educate the beef producers on biosecurity procedures should be considered.

2. More information about biosecurity and agroterrorism should be available to beef producers in West Virginia.

3. All beef producers should be encouraged to become Beef Quality Assurance (BQA) certified.

4. Studies should be conducted on other livestock species in West Virginia to determine biosecurity practices and educational needs.

5. A study should be conducted to determine the availability and accuracy of biosecurity information available through various channels.

6. Homeland Security and Extension should consider writing articles for farm magazines on biosecurity measures, since that is the preferred means of securing published information on biosecurity. 


\section{REFERENCES}

Ary, D., Jacobs, C., Razavieh, A., Sorenson. (2006). Introduction to research in education. (7th ed.). Belmont, CA: Thomson Wadsworth.

Buhman, M., Dewett, G., \& Griffin, D. (2007). Biosecurity basics for cattle operations and good management practices (GMP) for controlling infectious disease (G001411-A). Retrieved from Nebraska Cooperative Extension web-site: http://ianrpubs.unl.edu/epublic/pages.publicationD.jsp?publicationID $=433$

Clemens, R., (2007). After the ban: U.S. beef exports to Japan lag demand. (Iowa Ag Review on-line 13(1), 10-11). Retrieved from Iowa State University, Center for Agricultural and Rural Development web-site: http://www.card.iastate.edu/iowa_ag_review/winter_07/article5.aspx

Dargratz, D., Garry, F. \& Dargatz, J. (2002). An introduction to biosecurity of cattle operations. (Vet Clinical Food Animal, 18, 1-5). Retrieved from United States Department of Agriculture, National Agricultural Library web-site: http://hdl.handle.net/10113/23392

Degraw, J. (2005). Perceptions of Florida Beef Producers on Preparedness for an Agroterrorism Attack. (Unpublished master's thesis). University of Florida, Gainesville, FL.

Dillman, D.A. (2007). Mail and Internet surveys: The tailored design method (2nd ed.). New Jersey: John Wiley.

Jayarao, B., Tewari, D., \& Wolfgang, D. Agroterrorism: A potential threat to US animal agriculture-I. ). Retrieved from Penn State College of Agricultural Sciences, Veterinary and Biomedical Science web-site:

http://vbs.psu.edu/extension/resources-repository/publications/Agroterrorism1.pdf/view

Kelly, A. M., (2005). Veterinary medicine in the $21^{\text {st }}$ century: The challenge of biosecurity. Institute of Laboratory Animal Resources Journal, 46(1), 62-63. Retrieved from http://delsold.nas.edu/ilar_n/ilarjournal/46_1/pdfs/v4601Kelly.pdf

Krejcie, R.V. \& Morgan, D.W. (1960). Determining sample size for research activities. Educational and Psychological Measurement, 30, 607-610.

Meyerson, L.A. \& Reaser, J.K. (2002). Biosecurity moving toward a comprehensive approach. Bioscience, 52 (7), 593-600. Retrieved from http://nrs.uri.edu/labs/invasive/PdfReprints/Meyerson\&Rearson2002_BioSciences .pdf 
Robinson, J., Shaver P., Wrightsman, L. (1991). Measures of personality and social psychological attitudes. (pp 1-16) New York: Academic Press.

Sanderson, M., Dargatz, D., \& Garry, F. (2000). Biosecurity practices of beef cow-calf producers. Journal of the American Veterinary Medical Association, 217(2), 185189.

Schneider, R. Goodrich, Schneider, K.R., Webb, C.D., Hubbard, M., \& Archer, D.L. (2009). Agroterrorism in the U.S.: An overview (FSHN0521). Retrieved from University of Florida IFAS Extension web-site: http://edis.ifas.ufl.edu/fs126

United States Animal and Plant Health Inspection Service (APHIS). (2007). Biosecurity protecting your livestock and poultry. Riverdale, MD: U.S. Department of Agriculture, Animal and Plant Health Inspection Service, 2007.

United States Congress, Senate Committee on Homeland Security and Government Affairs (DHS). (2005). Homeland security food and agriculture Act of 2005: Report of the committee on Homeland Security and Government Affairs, United States Senate, to accompany S. 572 to amend the Homeland Security Act of 2002 to give additional biosecurity responsibilities to the Department of Homeland Security. Washington DC: U.S. G. P.O., 2005.

United States Department of Agriculture. (2006) Pre-Harvest Security Guidelines and Checklist 2006. Washington DC.

Valergakis, G., Arsenos, G., \& Konomou, G. (2008). Biosecurity measures on cattle farms. Journal of the Hellenic Veterinary Medical Society, 5a (1), 9-22.

Wolfgang, D. (n.d.) Biosecurity a Practical Approach. Penn State College of Agriculture Sciences. Retrieved from Penn State College of Agricultural Sciences, Cooperative Extension, Veterinarian Science Information web-site: vbs.psu.edu/extension/resources-repository/.../BiosecurityIRS.pdf. 
APPENDICES 
APPENDIX A

Initial Cover Letter 
April 12, 2010

Dear West Virginia Beef Producers:

As a beef producer you know the importance of keeping your herd safe and free of diseases. You have an appreciation for the time and effort that goes into your beef herd. Biosecurity is the key to keeping your herd safe. We are interested in the biosecurity practices you have implemented on your farm. Please take a few moments and share your opinions with us.

I am Rebecca Ours, a graduate student in Agricultural and Extension Education at West Virginia University. Under the direction of my advisor, Dr. Deborah Boone, I am conducting a research study to determine biosecurity practices currently implemented by beef producers. The results of this research study will be used to prepare a thesis to partially fulfill the requirements of a Master of Science degree in Agricultural and Extension Education. The results will provide insight to other beef producers and Extension educators about beef producers' biosecurity practices. West Virginia University's IRB acknowledgement of this research is on file.

Participation in this research study, while voluntary, will only take a few minutes of your time. You may skip any question you are not comfortable answering or may quit at any point and return the partially completed questionnaire. All information will be held as confidential as possible. Survey results will be reported in a summary format and individual responses will not be identifiable. You will notice a code number on the return envelope. This will be used to identify non-respondents for follow up. This code will be destroyed before the data are analyzed. There is no penalty and no services will be withheld if you choose not to participate.

We thank you in advance for your participation in the study. Please return the completed survey by Wednesday April 28, 2010 using the enclosed envelope. For questions, you may contact Dr. Boone at debby.boone@mail.wvu.edu or by phone at 304-293-5450 or Rebecca at rours1@mix.wvu.edu. Thank you, we sincerely appreciate your time and effort.

Sincerely,

Rebecca L. Ours

Graduate Student
Deborah A. Boone, Ph.D.

Associate Professor 
APPENDIX B

Instrument 


\section{Agricultural Security Risks Survey for West Virginia Beef Producers}

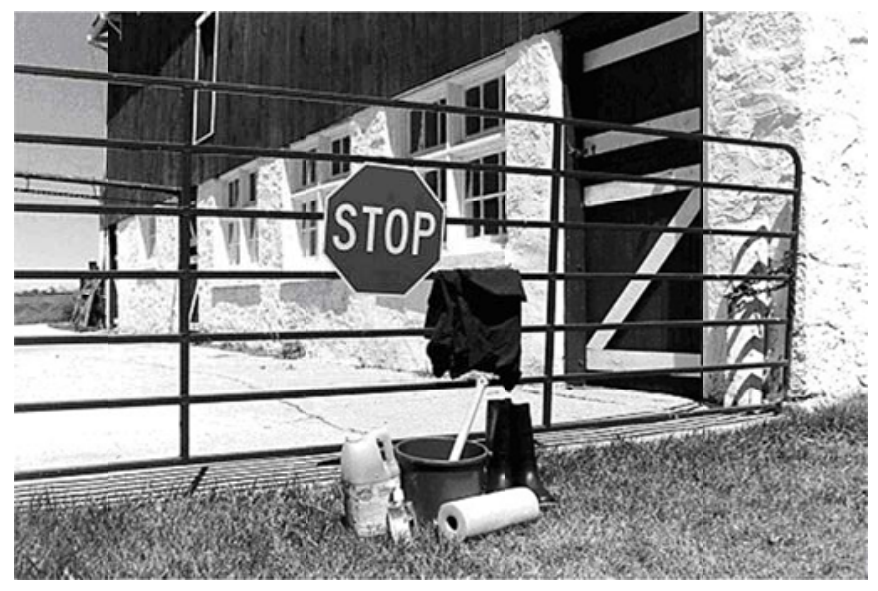

\section{Rebecca Ours}

Graduate Student

Agricultural and Extension Education

Davis College of Agriculture, Natural Resources and Design

West Virginia University

Morgantown, WV 26506 
This page intentionally left blank 


\section{Agricultural Security Risks Survey for Beef Producers \\ Part 1 - Perceptions about Agroterrorism}

Agroterrorism refers to an act of any person knowingly or maliciously using biological and/or chemical agents as weapons against the agricultural industry and/or the food supply, or using agricultural chemicals and machinery to perform an act of terrorism against any segment of the American population.

Instructions: Using the following Likert scale, rate your opinion on each of the following statements. Indicate your opinion by circling the letters that best corresponds to your response: SA - Strongly Agree, A-Agree, $N$-Neither Agree or Disagree, $D$ Disagree, or SD - Strongly Disagree.

\begin{tabular}{|c|c|c|c|c|c|}
\hline & 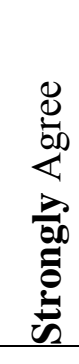 & 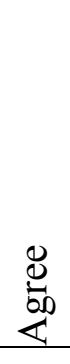 & 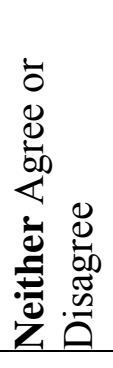 & 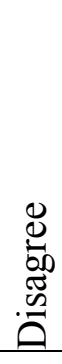 & 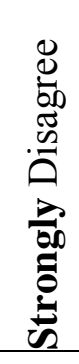 \\
\hline $\begin{array}{l}\text { 1. I think that an act of agroterrorism could } \\
\text { happen somewhere in the United States. }\end{array}$ & SA & A & $\mathrm{N}$ & $\mathrm{D}$ & SD \\
\hline $\begin{array}{l}\text { 2. I think that an act of agroterrorism could } \\
\text { happen somewhere in West Virginia. }\end{array}$ & SA & A & $\mathrm{N}$ & $\mathrm{D}$ & SD \\
\hline $\begin{array}{l}\text { 3. I think that an act of agroterrorism could } \\
\text { happen on my operation. }\end{array}$ & SA & A & $\mathrm{N}$ & D & SD \\
\hline $\begin{array}{l}\text { 4. I feel prepared for an agroterrorism } \\
\text { attack or some other biosecurity threat to } \\
\text { my operation. }\end{array}$ & SA & A & $\mathrm{N}$ & $\mathrm{D}$ & SD \\
\hline
\end{tabular}




\section{Part II - Rate the Level of Perceived Threat}

Instructions: Using the following Likert scale, rate the Level of Perceived Threat you feel for each aspect of your operation. Indicate your opinion by circling the number that best corresponds to your response: 5 -Considerable threat, 4-Much threat, 3 - Some threat, 2 - Little threat, or 1 - No threat.

\begin{tabular}{|c|c|c|c|c|c|}
\hline & 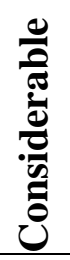 & $\bar{\Xi}$ & क् & 总 & ż \\
\hline 5. Water contamination & 5 & 4 & 3 & 2 & 1 \\
\hline 6. Feed contamination & 5 & 4 & 3 & 2 & 1 \\
\hline 7. Animal death & 5 & 4 & 3 & 2 & 1 \\
\hline 8. Animal disease outbreak & 5 & 4 & 3 & 2 & 1 \\
\hline 9. Fertilizer theft/misuse & 5 & 4 & 3 & 2 & 1 \\
\hline 10. Employee revenge & 5 & 4 & 3 & 2 & 1 \\
\hline 11. Chemical contamination & 5 & 4 & 3 & 2 & 1 \\
\hline $\begin{array}{l}\text { 12. Zoonotic illness } \\
\text { (Disease transmitted from animal to human) }\end{array}$ & 5 & 4 & 3 & 2 & 1 \\
\hline 13. Loss of income due to market loss & 5 & 4 & 3 & 2 & 1 \\
\hline 14. Tampering with facilities & 5 & 4 & 3 & 2 & 1 \\
\hline 15. Tampering with fences/gates & 5 & 4 & 3 & 2 & 1 \\
\hline 16. Other, please specify: & 5 & 4 & 3 & 2 & 1 \\
\hline
\end{tabular}

\section{Part III - Gaining Knowledge about Agroterrorism}

17. Have you attended a workshop or general information session about biosecurity/agroterrorism?

a) Yes, at least once

b) More than once

c) $\mathrm{No}$ 
18. If you suspected an act of agroterrorism (or breach of security) on your operation, from whom would you seek advice? (Select the three you would most likely contact).
a) Veterinarian
b) Extension Agent
c) West Virginia Department of Agriculture
d) Another livestock producer
e) Law enforcement
f) USDA
g) Producer Association
h) State Emergency Management
i) County Emergency Management
j) Homeland Security
k) Don't know
1) Other (please specify)

19. Have you made considerable investments (time, money or effort) to make your operation more biosecure?
a) Yes, before September 11, 2001
b) Yes, before and after September 11, 2001
c) Yes, after September 11, 2001
d) No
e) Don't know 


\section{Part IV - Agroterrorism Preparedness}

Below is a list of safeguards that one may practice on the farm in order to reduce the likelihood of loss of production due to disease introduction.

Instructions: To the Left, circle the number which represents your opinion of the importance of the safeguard to better protect your livestock operation. Indicate your opinion by circling the number which best reflects your response: 4 - Major Importance, 3 - Moderate Importance, 2 - Minor Importance, or 1 - No Importance. .

To the Right, circle the degree to which you practice the indicated safeguard on your livestock operation. Indicate your opinion by circling the number which best reflects your response: 4 - Always Practice, 3 - Moderate Practice, 2 - Rarely Practice, 1 Never Practice, or NA - Not Applicable.

\begin{tabular}{|c|c|c|c|c|c|c|c|c|c|}
\hline \multicolumn{4}{|c|}{$\begin{array}{l}\text { Importance of the } \\
\text { Safeguard }\end{array}$} & & \multicolumn{5}{|c|}{$\begin{array}{c}\text { Degree to Which You } \\
\text { Practice }\end{array}$} \\
\hline 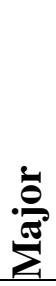 & 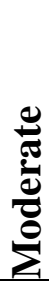 & 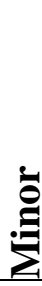 & 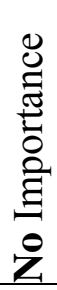 & & $\frac{\sum_{2}^{\infty}}{2}$ & 苞 & 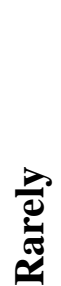 & 己 & $\begin{array}{l}\frac{0}{0} \\
\frac{0}{0} \\
\frac{0}{2} \\
\frac{0}{2} \\
\frac{0}{z}\end{array}$ \\
\hline 4 & 3 & 2 & 1 & 20. Limiting visitors & 4 & 3 & 2 & 1 & NA \\
\hline 4 & 3 & 2 & 1 & $\begin{array}{l}\text { 21. Requiring a waiting period for } \\
\text { visitors who have been on } \\
\text { another farm }\end{array}$ & 4 & 3 & 2 & 1 & NA \\
\hline 4 & 3 & 2 & 1 & $\begin{array}{l}\text { 22. Isolating a new animal for } \\
\text { observation before introducing } \\
\text { it to the entire herd. }\end{array}$ & 4 & 3 & 2 & 1 & NA \\
\hline 4 & 3 & 2 & 1 & $\begin{array}{l}\text { 23. Requiring employees to wear } \\
\text { overalls }\end{array}$ & 4 & 3 & 2 & 1 & NA \\
\hline 4 & 3 & 2 & 1 & $\begin{array}{l}\text { 24. Requiring employees to wear } \\
\text { shoe covers }\end{array}$ & 4 & 3 & 2 & 1 & NA \\
\hline
\end{tabular}




\begin{tabular}{|c|c|c|c|c|c|c|c|c|c|}
\hline \multicolumn{4}{|c|}{$\begin{array}{l}\text { Importance of the } \\
\text { Safeguard }\end{array}$} & & \multicolumn{5}{|c|}{$\begin{array}{l}\text { Degree to Which You } \\
\text { Practice }\end{array}$} \\
\hline 高 & 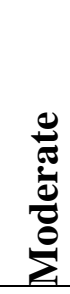 & 总 &  & & 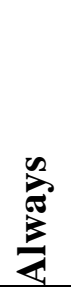 & 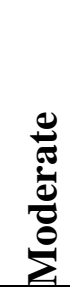 &  & 离 & 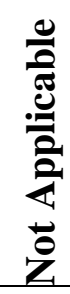 \\
\hline 4 & 3 & 2 & 1 & $\begin{array}{l}\text { 25. Requiring visitors to use } \\
\text { footbaths }\end{array}$ & 4 & 3 & 2 & 1 & NA \\
\hline 4 & 3 & 2 & 1 & $\begin{array}{l}\text { 26. Requiring employees to use } \\
\text { footbaths }\end{array}$ & 4 & 3 & 2 & 1 & NA \\
\hline 4 & 3 & 2 & 1 & $\begin{array}{l}\text { 27. Requiring visitors to wear } \\
\text { gloves }\end{array}$ & 4 & 3 & 2 & 1 & NA \\
\hline 4 & 3 & 2 & 1 & $\begin{array}{l}\text { 28. Requiring employees to wear } \\
\text { gloves }\end{array}$ & 4 & 3 & 2 & 1 & NA \\
\hline 4 & 3 & 2 & 1 & $\begin{array}{l}\text { 29. Requiring visitors to stop at a } \\
\text { biosecurity checkpoint before } \\
\text { entering the farm }\end{array}$ & 4 & 3 & 2 & 1 & NA \\
\hline 4 & 3 & 2 & 1 & $\begin{array}{l}\text { 30. Requiring people entering the } \\
\text { farm to shower before entering }\end{array}$ & 4 & 3 & 2 & 1 & NA \\
\hline 4 & 3 & 2 & 1 & $\begin{array}{l}\text { 31. Requiring people leaving the } \\
\text { farm to shower before leaving }\end{array}$ & 4 & 3 & 2 & 1 & NA \\
\hline 4 & 3 & 2 & 1 & $\begin{array}{l}\text { 32. Requiring visitors to disinfect } \\
\text { vehicles entering farm }\end{array}$ & 4 & 3 & 2 & 1 & NA \\
\hline 4 & 3 & 2 & 1 & $\begin{array}{l}\text { 33. Conducting a background } \\
\text { check on potential hires }\end{array}$ & 4 & 3 & 2 & 1 & NA \\
\hline 4 & 3 & 2 & 1 & $\begin{array}{l}\text { 34. Have regular meetings with } \\
\text { employees to determine levels } \\
\text { of their satisfaction }\end{array}$ & 4 & 3 & 2 & 1 & NA \\
\hline 4 & 3 & 2 & 1 & $\begin{array}{l}\text { 35. Participate in training } \\
\text { program(s) that will enable } \\
\text { employees to quickly recognize } \\
\text { and report a disease }\end{array}$ & 4 & 3 & 2 & 1 & NA \\
\hline
\end{tabular}


Instructions: Using the following Likert scale, rate the likelihood you would contact the individual/agency for additional information about agroterrorism or livestock specific biosecurity threats. Indicate your opinion by circling the number which best reflects your opinion using: 5 - Very likely, 4 - Fairly likely, 3 - Likely, 2 - Unlikely, or 1 - Very unlikely.

\begin{tabular}{|c|c|c|c|c|c|}
\hline & 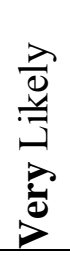 & 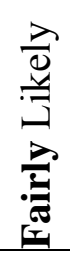 & 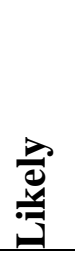 & 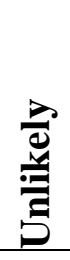 & 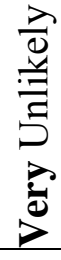 \\
\hline 36. Veterinarian & 5 & 4 & 3 & 2 & 1 \\
\hline 37. Extension agent & 5 & 4 & 3 & 2 & 1 \\
\hline 38. West Virginia Dept. of Agriculture & 5 & 4 & 3 & 2 & 1 \\
\hline 39. Another livestock producer & 5 & 4 & 3 & 2 & 1 \\
\hline 40. Law enforcement & 5 & 4 & 3 & 2 & 1 \\
\hline 41. United States Department of Agriculture & 5 & 4 & 3 & 2 & 1 \\
\hline 42. Producer Association & 5 & 4 & 3 & 2 & 1 \\
\hline 43. State or County Emergency Management & 5 & 4 & 3 & 2 & 1 \\
\hline 44. Homeland Security & 5 & 4 & 3 & 2 & 1 \\
\hline 45. State Emergency Management & 5 & 4 & 3 & 2 & 1 \\
\hline 46. County Emergence Management & 5 & 4 & 3 & 2 & 1 \\
\hline 47. Farm Bureau & 5 & 4 & 3 & 2 & 1 \\
\hline 48. West Virginia Beef Council & 5 & 4 & 3 & 2 & 1 \\
\hline 49. West Virginia Beef Cattleman's Association & 5 & 4 & 3 & 2 & 1 \\
\hline 50. Agriculture Teachers & 5 & 4 & 3 & 2 & 1 \\
\hline 51. West Virginia Beef Specialist & 5 & 4 & 3 & 2 & 1 \\
\hline $\begin{array}{l}\text { 52. West Virginia University-Davis College of } \\
\text { Agriculture, Natural Resources and Design }\end{array}$ & 5 & 4 & 3 & 2 & 1 \\
\hline 53. Potomac State College & 5 & 4 & 3 & 2 & 1 \\
\hline
\end{tabular}




\begin{tabular}{|c|c|c|c|c|c|}
\hline & 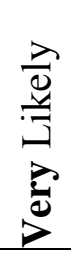 & 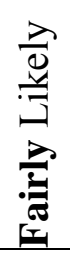 & 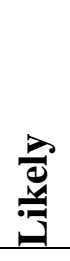 & 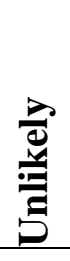 & 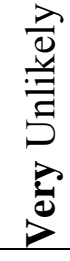 \\
\hline 54. Don't know who I would contact & 5 & 4 & 3 & 2 & 1 \\
\hline 55. Other, please specify: & 5 & 4 & 3 & 2 & 1 \\
\hline
\end{tabular}

56. Do you have access to educational material that can answer your beef cattle biosecurity questions? If you answer "Yes", please write in the material source in the blank space below:

a) Yes;

b) No

c) Don't Know 
Instructions: Using the following Likert scale, rate the likelihood you use the following sources of published information for additional information about agroterrorism or livestock specific biosecurity threats. Indicate your opinion by circling the number which best reflects your opinion using: 5 - Very likely, 4 - Fairly likely, 3 - Likely, 2 Unlikely, or 1 - Very unlikely.

\begin{tabular}{|c|c|c|c|c|c|}
\hline & 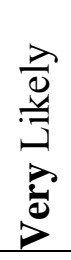 & 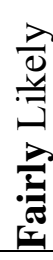 & $\begin{array}{l}\frac{d}{d} \\
\frac{d}{3} \\
\frac{1}{3}\end{array}$ & 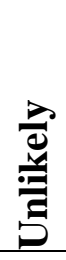 & 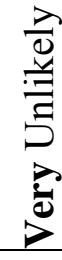 \\
\hline 57. Farm Magazine & 5 & 4 & 3 & 2 & 1 \\
\hline 58. Newspaper & 5 & 4 & 3 & 2 & 1 \\
\hline 59. Internet (World Wide Web) & 5 & 4 & 3 & 2 & 1 \\
\hline 60. Library Publications & 5 & 4 & 3 & 2 & 1 \\
\hline 61. Extension Office & 5 & 4 & 3 & 2 & 1 \\
\hline 62. West Virginia University & 5 & 4 & 3 & 2 & 1 \\
\hline 63. Other, please specify: & 5 & 4 & 3 & 2 & 1 \\
\hline
\end{tabular}

64. To what extent has the Foot and Mouth outbreak in England and the December 2003 discovery of Bovine Spongiform Encephalopathy (BSE) case in the U.S. influenced any decisions towards improving the security on your operation?

a) Strongly Influenced

b) Influenced

c) Neither

d) Minimal Influence

e) No Influence

65. What is your gender?

\section{Part V - Demographics}

a) Male

b) Female 
66. How many years have you been in the beef cattle business? Select one.

a) 1 day -12 months

b) 13 months -2 years

c) 25 months -3 years

d) 37 months -4 years

e) 49 months -5 years

f) 61 months -6 years

g) 73 months -7 years

h) More than 7 years

67. Please select the number of cattle on your production facility during your peak time of the year (when you are at your highest maximum). Select one.

a) $1-20$ animals

b) $21-50$ animals

c) $51-100$ animals

d) $101-200$ animals

e) $201-300$ animals

f) $301-500$ animals

g) $501+$ animals

68. How do you describe yourself?

a) Owner/Operator

b) Operator on land you own

c) Operator on rented/leased land

d) Other (specify)

69. Would you attend an educational program about agroterrorism/biosecurity?

a) Yes

b) No

c) Not sure

70. If an educational program were to concentrate on educating beef producers about agroterrorism when would prefer delivery method?

a) Weekends

b) Evenings

c) Weekdays 
71. If an educational program were to concentrate on educating beef producers about agroterrorism how would you prefer delivery method? Please select your top three choices:

a) Trainings

b) Read printed materials at your own pace

c) Take classes on the Internet

d) One-on-One contact

e) Dinner meetings

f) Demonstrations

g) Computer software

h) Lectures

i) Video/DVD

j) Audio cassettes/CDs

k) Group work

1) Fact sheet

m) Books

\section{Part V - Operation Demographics}

72. How many acres do you own?

a) None

b) Less than 1 acre to 99 acres

c) $100-249$ acres

d) $250-499$ acres

e) 500 - 999 acres

f) $1000-1999$ acres

g) 2000 - or more acres

73. How many acres do you rent/lease?

a) None

b) Less than 1 acre to 99 acres

c) $100-249$ acres

d) $250-499$ acres

e) 500 - 999 acres

f) $1000-1999$ acres

g) 2000 - or more acres 
74. What is the average value of your annual gross receipts for the beef cattle-related segment of your operation?

a) Less than $\$ 9,999$

b) $\$ 10,000-\$ 49,999$

c) $\$ 50,000-\$ 99,000$

d) $\$ 100,000-\$ 249,000$

e) $\$ 250,000-499,999$

f) $\$ 500,000-\$ 999,999$

g) $\$ 1,000,000-$ or more

75. Is your farm registered in the National Animal Identification System?

a) Yes

b) No

c) Not sure

76. Do you have Beef Quality Assurance (BQA) certification?

a) Yes

b) No

c) Not sure

77. How many people do you employ on your farm full time? (other than family)

a) None

b) 1-2

c) 3-4

d) More than 4

78. How many people do you employ on your farm part time? (other than family)

a) None

b) 1-2

c) $3-4$

d) More than 4

Comments: 
This page intentionally left blank 
If you have any questions regarding this survey please feel free to contact: Rebecca Ours by email: rours1@mix.wvu.edu or

Dr. Debby Boone at 304-293-5450 or email at debby.boone@mail.wvu.edu

Thank you for taking the time to complete this survey. We greatly appreciate your input. 
APPENDIX C

Follow-up Cover Letter 
April 30, 2010

Dear West Virginia Beef Producers:

Several weeks ago, you received a survey, seeking input on your opinions regarding biosecurity practices as it relates to your beef cattle operation. Your input is vital to this study and your participation is appreciated. I hope you will take a few minutes to fill out the survey and return it in the postage paid envelope. As a beef producer you know the importance of keeping your herd safe and free of diseases. You have an appreciation for the time and effort that goes into your beef herd. Biosecurity is the key to keeping your herd safe. We are interested in the biosecurity practices you have implemented on your farm. Please take a few moments and share your opinions with us.

I am Rebecca Ours, a graduate student in Agricultural and Extension Education at West Virginia University. Under the direction of my advisor, Dr. Deborah Boone, I am conducting a research study to determine biosecurity practices currently implemented by beef producers. The results of this research study will be used to prepare a thesis to partially fulfill the requirements of a Master of Science degree in Agricultural and Extension Education. The results will provide insight to other beef producers and Extension educators about beef producers' biosecurity practices. West Virginia University's IRB acknowledgement of this research is on file.

Participation in this research study, while voluntary, will only take a few minutes of your time. You may skip any question you are not comfortable answering or may quit at any point and return the partially completed questionnaire. All information will be held as confidential as possible. Survey results will be reported in a summary format and individual responses will not be identifiable. You will notice a code number on the return envelope. This will be used to identify non-respondents for follow up. This code will be destroyed before the data are analyzed. There is no penalty and no services will be withheld if you choose not to participate.

We thank you in advance for your participation in the study. Please return the completed survey by Monday, May 17, 2010 using the enclosed envelope. For questions, you may contact Dr. Boone at debby.boone@mail.wvu.edu or by phone at 304-293-5450 or Rebecca at rours1@mix.wvu.edu. Thank you, we sincerely appreciate your time and effort.

Sincerely,

Rebecca L. Ours

Graduate Student
Deborah A. Boone, Ph.D. Associate Professor 
APPENDIX D

Comments 


\section{Comments}

Responses:

Went to WV Beef Expo and no biosecurity measures. Bureaucrats will nothing to help small operators if a problem happens except shoot them down and talk endlessly about it. Just like this survey, looks good but nothing real will come of it!

For someone to even think that It Is unlikely to have problems In the Food production Industry In this Country From terrorists Is Being Foolish. It would Be Very Easy to mess up Our Food Supply (meats, Etc.). We must Guard Against this to the Point to have our "Guns" Loaded at all Times. WE have already had some problems From Cattle Rustling. Since Sept. 11, 2001 Anything can happen. That has Already Been Proven In this Country. May God Bless America And Its Farmers.

Coveralls \& Boots relate to my poultry operation and not my Beef operation. Thank you! Good Luck in M.S. Program.

I don't want to give the impression that I am not concerned about disease or terrorism but a lot of farms have a heavy flow of people and automobiles, which make it quite a difference. I have a small operation, a cow-calf program in which I sell all my calves in a pool once a year. We take all precautions as far as vaccine and parasite controls are concerned. Have very few visitors. Extension Service would have the material or know where to get it. 
With no "feedlot" markets in WV, no assistance available at a "common sense" practical/logical approach for beef producers. Why worry about agroterrorism? It is also obvious that the only thing [Commissioner of Agriculture] worries about is the next free trip w/ [wife]. He certainly has not tried to help in any way the cattle breeders in WV.

I think this is a good survey. I also think we need to educate everyone in the U.S.A. about agroterrorism. There is too many people $\mathrm{n}$ the USA that doesn't even know where there food comes from. No Farm- No Food.

We do not have a Biosecurity Plan for our farm. To my knowledge the WVU extension needs to start a program train their agents. Keep up the good work, maybe you can make a change for the farmers of WV

Good Luck on Your Thesis!

I am 84yrs old and just try to purchase a few cattle to summer on my limited amount of grazing. Our capacity is 15 to 20 head of yearlings.

Best of Luck w/ your project.

Note: The BSE Case in 2003 was economical disaster for cattle producers, yet Canadian Border still open. It is hard to take serious a threat of biosecurity when the policy of the USDA is to continue an open border policy for trade and market access to maintain a 
cheap food supply. If we were really concerned for the safety of our national herds we would not continue to allow cattle pour across the borders from Canada and Mexico.

If you would have meetings Cedar Lakes would be a great place to have them.

Too old to Farm

Extensions agents in previous years would visit my farm but the last two we've never seen, only at the fair.

You could get scared about it. But I am not sacred. G.E.M. 
APPENDIX E

Open Ended Responses 
Open Ended Responses

Question 16: Rate the level of perceived threat you feel for each aspect of your operation.

Responses:

Killing Cattle

Rail trail runs thru farm. The general public is invited there, by government organizations.

Fire

Prices of beef dropping

Question 18 LA: If you suspected an act of terrorism (or breech of security) on your operation, from whom would you seek advice?

Responses:

Shoot the SOB

FBI wife works there

Handle myself

Question 55 A: The likelihood you would contact the individual/agency for additional information about agroterrorism or livestock specific biosecurity threats. Responses:

Stockyard

Question 56: Do you have access educational material that can answer your beef cattle biosecurity questions?

Responses:

Computer (3)

Computer Internet 
Correll [sic] U. Local Vets, Drovers

County Extension Agent

County Extension Agent Ed Smolder

Don’t Care!

Internet

Ever County High Schools Ag Dept.

Ext. Agent

Extension Agent (3)

Extension Service, They have the material or can get it.

Farm Magazine

Farm Service Agency

Grandson is ext agent

Internet (14)

Internet search

Library

local and state specialist

Magazines

market bulletin

market bulletin W.V.

ON THE WEB

PSU Ag

USDA

USDA Agroterrorism Handbook 
WVDA (2)

WVU (2)

WVU Ag

WVU Extension

Question 68 A: How do you describe yourself?

Responses:

All of the above

Owner/partner

Lease out Ag Land

Co-owner/Operator

Raise beef for own use

Operator-family member

Partnership

Question 69 A: Would you attend an educational program about agroterrorism/biosecurity?

Responses:

Depends on location and convenience 
VITA

Rebecca Laura Ours

Education:

May 2008

May 2008

December 2008

December 2010
Associate of Arts

Animal and Vet Science

Potomac State College of WVU

Keyser, West Virginia

Associate of Arts

General Agriculture

Potomac State College of WVU

Keyser, West Virginia

Bachelor of Science

Animal and Nutritional Sciences

West Virginia University

Morgantown, West Virginia

Master of Science

Agricultural and Extension Education

West Virginia University

Morgantown, West Virginia

Summer Intern

Hardy County Extension Service

Agricultural and Natural Resources

West Virginia University

Moorefield, WV
May 2009-

August 2009

May 2010 -

August 2010 